UC-25 Metallurgy and Ceramics (TID-4500, 15th Ed.)

\title{
DETERMINATION OF INTERSTITIAL SOLID-SOLUBILITY LIMIT IN TANTALUM AND IDENTIFICATION OF THE PRECIPITATE PHASES
}

\section{by}

Dale A. Vaughan

Oliver M. Stewart

Charles M. Schwartz

October 28, 1960

\author{
BATTELLE MEMORIAL INSTITUTE \\ 505 King Avenue \\ Columbus 1, Ohio
}




\section{DISCLAIMER}

This report was prepared as an account of work sponsored by an agency of the United States Government. Neither the United States Government nor any agency Thereof, nor any of their employees, makes any warranty, express or implied, or assumes any legal liability or responsibility for the accuracy, completeness, or usefulness of any information, apparatus, product, or process disclosed, or represents that its use would not infringe privately owned rights. Reference herein to any specific commercial product, process, or service by trade name, trademark, manufacturer, or otherwise does not necessarily constitute or imply its endorsement, recommendation, or favoring by the United States Government or any agency thereof. The views and opinions of authors expressed herein do not necessarily state or reflect those of the United States Government or any agency thereof. 


\section{DISCLAIMER}

Portions of this document may be illegible in electronic image products. Images are produced from the best available original document. 
ABSTRACT

INTRODUCTION

EXPERIMENTAL WORK AND RESULTS .

X-Ray Diffraction Studies .

Metallographic Investigations

High-Purity Tantalum

Tantalum-Carbon System

Tantalum-Nitrogen System

Tantalum-Oxygen System

DISCUSSION OF RESULTS

ACKNOWLEDGMENT . . . . . . . . . . . . . . . . . . . . . 28

REFERENCES . . . . . . . . . . . . . . . . . . . . . . 28 


\section{DETERMINATION OF INTERSTITIAL SOLID-SOLUBILITY \\ LIMIT IN TANTALUM AND IDENTIFICATION \\ OF THE PRECIPITATE PHASES}

Dale A. Vaughan, Oliver M. Stewart, and Charles M. Schwartz

Solid-solubility limits at 1500,1000, and $500 \mathrm{C}$ for carbon, nitrogen, and oxygen in high-purity tantalum were determined by X-ray lattice-parameter methods. For carbon, the solubility was found to be $0.17 \mathrm{a} / 0$ at $1500 \mathrm{C}$ and less than $0.07 \mathrm{a} / 0$ at $1000 \mathrm{C}$. A nitrogen solubility of $3.70 \mathrm{a} / 0$ at $1500 \mathrm{C}$ decreases linearly with temperature to $2.75 \mathrm{a} / \mathrm{o}$ at $1000 \mathrm{C}$ and $1.8 \mathrm{a} / \mathrm{o}$ at $500 \mathrm{C}$. In the case of oxygen, the solubility was found to be 3.65 a/o at $1500 \mathrm{C}, 2.95$ $\mathrm{a} / \mathrm{o}$ at $1000 \mathrm{C}$, and $2.5 \mathrm{a} / 0$ at $500 \mathrm{C}$. The phases $\mathrm{T}_{2} \mathrm{C}$, the low-temperature modification of $\mathrm{Ta}_{2} \mathrm{O}_{5}$, and $\mathrm{Ta}_{x} \mathrm{~N}$ of unknown composition but which has a superlattice structure based upon the original body-centered-cubic tantalum lattice have been identified as the initial precipitates in the respective systems.

\section{INTRODUCTION}

The excellent fabricability, high melting point, and nuclear properties of tantalum are responsible for interest in this refractory metal as a container material for the Los Alamos Molten Plutonium Reactor Experiment (LAMPRE). However, metallographic studies by LASL on high-purity tantalum after exposure to molten-plutonium fuel mixtures suggested that precipitate phases were being attacked by this corrosive medium. Since the interstitial elements, carbon, nitrogen, and oxygen, were the major impurities, it was of interest to determine the solid solubility of these elements in tantalum at 1500 , 1000 , and $500 \mathrm{C}$ and to identify the precipitate phases in each system which might relate to the effect observed by LASL.

Gebhardt et al. (1-3) have investigated the tantalum-oxygen and tantalum-nitrogen systems with particular reference to the changes in physical properties and to the rates of reaction between these gases and the metal. The solid solubility of oxygen in tantalum was reported(2) to be 3.7 a/o at $1500 \mathrm{C}, 2.3 \mathrm{a} / \mathrm{o}$ at $1000 \mathrm{C}$, and $1.4 \mathrm{a} / \mathrm{o}$ at $750 \mathrm{C}$. The compounds in the tantalum-oxygen system give complex X-ray diffraction patterns.

Schonberg(4) reported that several oxide phases $\left(\mathrm{Ta}_{4} \mathrm{O}, \mathrm{Ta} 2 \mathrm{O}, \mathrm{TaO}_{2}\right.$, and $\mathrm{Ta}_{2} \mathrm{O}_{5}$ ) exist while $\mathrm{X}$-ray studies by Gebhardt(1) showed only two oxides, $\mathrm{Ta}_{2} \mathrm{O}_{5}$ and an unidentified phase which was associated with a platelet-type precipitate. Lagergren and Magneli(5), however, questioned the existence of compounds other than the two allotropic modifications of $\mathrm{Ta}_{2} \mathrm{O}_{5}$ for the tantalum-oxygen system. Although all of the reported compounds were considered as possible precipitate phases, the present investigation was not designed to prepare specific compounds but only to identify the precipitate phase that was observed in tantalum supersaturated with the various interstitial elements. Thus, no attempt was made to resolve the disagreement among the various reports as to the possible tantalum oxide phases.

(1) References at end. 
In the case of nitrogen, the solubility was established by Gebhardt( 3$)$ to be of the order of $7 \mathrm{a} / \mathrm{o}$ at $1800 \mathrm{C}$. The solubility was reported to decrease rapidly with temperature, and, although no limits were established, a precipitate phase was observed by Gebhardt except when the high-nitrogen specimens were cooled very rapidly from the reaction temperature of $1800 \mathrm{C}$. Gebhardt reported the initial precipitate phase to be a tetragonal distortion of the body-centered-cubic tantalum lattice while Schonberg(6) reported the phase lowest in nitrogen to be a cubic superlattice with a cell size of $10.11 \mathrm{~A}$. Two other nitride phases, $\mathrm{Ta}_{2} \mathrm{~N}$ and $\mathrm{TaN}$, were reported by Schonberg in his studies of the tantalum-nitrogen system. The latter two phases appear to be isomorphous with the carbides of tantalum.

The tantalum-carbon system was investigated by Ellinger(7) and by Lesser and Braurer ${ }^{(8)}$. Two compounds, $\mathrm{Ta}_{2} \mathrm{C}$ and $\mathrm{TaC}$, were reported to exist, each with a range of composition. The solubility of carbon in the tantalum lattice was reported to be practically nil at all temperatures. Thus, of the interstitial elements, which are present in small amounts in high-purity tantalum, carbon might be expected to form precipitates when the metal is employed as a molten-plutonium container.

The present investigation was initiated to obtain additional data on the solidsolubility limits of these interstitials at 1500, 1000, and $500 \mathrm{C}$ with particular emphasis on the distribution and the identification of the precipitate phases.

\section{EXPERIMENTAL WORK AND RESULTS}

In the present investigations of the solid solubility and of the precipitate phases in the systems tantalum-nitrogen, -oxygen, and-carbon, high-purity tantalum was reacted with high-purity gases, homogenized at $1800 \mathrm{C}$, and annealed at and quenched from 1500,1000 , and $500 \mathrm{C}$. Thirty-mil tantalum sheet (LASL Stock 565) was formed into 5/8-in. -OD cylindrical specimens, 1-1/2 in. long. An analysis of the as-rolled stock is given in Table 1. The specimens were etched in a solution containing $30 \mathrm{ml}$ of lactic, $10 \mathrm{ml}$ of nitric, and $10 \mathrm{ml}$ of hydrofluoric acids, then suspended, by tantalum wire, in a quartz reaction tube of a modified Seiverts apparatus for gas additions. Calculated amounts of oxygen, produced by the thermal decomposition of potassium permanganate, of nitrogen from Matheson prepurified nitrogen (99.96 per cent pure) or of methane gas were added to the evacuated reaction tube and the tantalum heated inductively until the gases were absorbed. In the case of oxygen and nitrogen additions, the reaction was shown by a drop in pressure as indicated by a vacuum gage. Less control was obtainable, however, for the carbon additions. Subsequent homogenizing and annealing treatments were made under high-purity argon to facilitate quenching after the annealing treatment. The argon aided in preparing the higher-gas-content specimens by reducing the amount of vaporization or decomposition during the final heat treatment. The homogenizing treatment was $3 \mathrm{hr}$ at $1800 \mathrm{C}$ while the annealing times were $3 \mathrm{hr}$ at $1500 \mathrm{C}, 24 \mathrm{hr}$ at $1000 \mathrm{C}$, and $100 \mathrm{hr}$ at $500 \mathrm{C}$.

The amounts of the interstitial elements absorbed and retained by the tantalum were determined by chemical assay on all samples after the $1500 \mathrm{C}$ anneal. Oxygen analyses were obtained by vacuum fusion, the nitrogen contents were obtained by microKjeldahl and the carbon analyzed by microcarbon methods. The results of these analyses are given in Tables 2,3 , and 4 , respectively. Specimens of the tantalum stock were heat 
TABLE 1. ANALYSIS OF TANT ALUM STOCK USED FOR PREPARATION OF OXYGEN, NITROGEN, AND CARBON ALLOYS

\begin{tabular}{lc}
\hline \hline Element $(\mathrm{a})$ & Content, ppm \\
\hline Magnesium & Trace, $<0.5$ \\
Iron & 1.0 \\
Nickel & Trace, $<0.1$ \\
Copper & Trace, $<0.5$ \\
Calcium & 1.0 \\
Chromium & Trace, $<1.0$ \\
Zirconium & $<10$ \\
Tungsten & Not detected, <100 \\
Oxygen & 12 \\
Nitrogen & 10 \\
Carbon & 50 \\
\hline
\end{tabular}

(a) No other metallic elements were detected.

TABLE 2. LATTICE -PARAMETER AND HARDNESS CHANGES IN TANTALUM WITH INCREASING OXYGEN CONTENT

\begin{tabular}{|c|c|c|c|c|c|c|}
\hline \multirow[b]{3}{*}{ Specimen } & & & \multirow{3}{*}{$\begin{array}{c}\text { Hardness, } \\
\text { KHN }\end{array}$} & \multicolumn{3}{|c|}{$\begin{array}{l}\text { Lattice Parameter, A, } \\
\text { After Indicated Anneal }\end{array}$} \\
\hline & \multicolumn{2}{|c|}{ Oxygen Content } & & \multirow{2}{*}{$\begin{array}{c}3 \mathrm{Hr}, \\
1500 \mathrm{C}\end{array}$} & \multirow{2}{*}{$\begin{array}{r}24 \mathrm{Hr} \\
1000 \mathrm{C}\end{array}$} & \multirow{2}{*}{$\begin{array}{l}100 \mathrm{Hr} \\
500 \mathrm{C}\end{array}$} \\
\hline & $w / 0$ & $a / o$ & & & & \\
\hline $22 \mathrm{~A}$ & 0.010 & 0.11 & 122 & 3.3033 & 3.3035 & -- \\
\hline $2 A$ & 0.010 & 0.11 & 201 & 3.3036 & -- & -- \\
\hline $4 \mathrm{~A}$ & 0.044 & 0.50 & 206 & 3.3052 & 3.3050 & 3.3051 \\
\hline $3 \mathrm{~A}$ & 0.086 & 1.02 & 216 & 3.3070 & -- & -. \\
\hline $11 \mathrm{~A}$ & 0.106 & 1.18 & 366 & 3.3080 & 3.3080 & -. \\
\hline $15 \mathrm{~A}$ & 0.134 & 1.49 & 356 & 3.3082 & 3.3086 & 3.3086 \\
\hline $38 \mathrm{~A}$ & 0.208 & 2.32 & -- & 3.3139 & -. & -. \\
\hline $34 \mathrm{~A}$ & 0.288 & 3.16 & 534 & 3.3182 & 3.3165 & 3.3140 \\
\hline $39 \mathrm{~A}$ & 0.398 & 4.32 & -- & 3.3200 & -- & -- \\
\hline $35 \mathrm{~A}$ & 0.483 & 5.27 & 1029 & 3.3198 & 3.3166 & 3.3145 \\
\hline
\end{tabular}


TABLE 3. LATTICE-PARAMETER AND HARDNESS CHANGES IN TANTALUM WITH INCREASING NITROGEN CONTENT

\begin{tabular}{|c|c|c|c|c|c|c|}
\hline \multirow[b]{2}{*}{ Specimen } & \multicolumn{2}{|c|}{ Nitrogen Content } & \multirow{2}{*}{$\begin{array}{c}\text { Hardness, } \\
\mathrm{KHN}\end{array}$} & \multicolumn{3}{|c|}{ Lattice Parameter, After Indicated Anneal } \\
\hline & $w / 0$ & $a / 0$ & & $4 \mathrm{Hr}, 1500 \mathrm{C}$ & $24 \mathrm{Hr}, 1000 \mathrm{C}$ & $100 \mathrm{Hr}, 500 \mathrm{C}$ \\
\hline $22 \mathrm{~A}$ & 0.001 & 0.01 & 122 & 3.3033 & 3.3035 & -- \\
\hline $30 \mathrm{~A}$ & 0.021 & 0.27 & 226 & 3.3046 & 3.3052 & - \\
\hline $23 \mathrm{~A}$ & 0.049 & 0.63 & 313 & 3.3053 & 3.3055 & 3.3070 \\
\hline $7 \mathrm{~B}$ & 0.085 & 1.09 & 345 & 3.3073 & + & -. \\
\hline $21 \mathrm{~B}$ & 0.115 & 1.46 & 451 & 3.3100 & 3.3083 & - \\
\hline $31 \mathrm{~A}$ & 0.159 & 2.01 & 497 & 3.3122 & 3.3129 & -. \\
\hline $32 \mathrm{~A}$ & 0.224 & 2.82 & 697 & 3.3160 & 3.3153 & -. \\
\hline $20 \mathrm{~B}$ & 0.274 & 3.42 & 814 & 3.3183 & - & 3.3114 \\
\hline $37 \mathrm{~A}$ & 0.290 & 3.62 & $-\infty$ & 3.3198 & -- & 3.3104 \\
\hline $33 \mathrm{~A}$ & 0.319 & 3.97 & 841 & 3. 3191 & 3.3153 & -. \\
\hline $36 \mathrm{~A}$ & 0.342 & 4.24 & 953 & 3. 3199 & -. & - \\
\hline $40 \mathrm{~A}$ & 0.490 & 5.98 & $\infty$ & - & - & $\cdots$ \\
\hline $41 \mathrm{~A}$ & 0.630 & 7.57 & -- & -- & - &.- \\
\hline
\end{tabular}

TABLE 4. LAT TICE-PARAMETER AND HARDNESS CHANGES IN TANTALUM WITH INCREASING CARBON CONTENT

\begin{tabular}{|c|c|c|c|c|c|}
\hline \multirow[b]{2}{*}{ Specimen } & \multicolumn{2}{|c|}{ Carbon Content } & \multirow{2}{*}{$\begin{array}{c}\text { Hardness, } \\
\mathrm{KHN}\end{array}$} & \multicolumn{2}{|c|}{$\begin{array}{c}\text { Lattice Parameter, After Indicated } \\
\text { Anneal }\end{array}$} \\
\hline & $\mathrm{w} / \mathrm{o}$ & $a / 0$ & & $4 \mathrm{Hr}, 1500 \mathrm{C}$ & $24 \mathrm{Hr}, 1000 \mathrm{C}$ \\
\hline $22 \mathrm{~A}$ & 0.005 & 0.07 & 122 & 3.3033 & 3.3035 \\
\hline $8 \mathrm{~A}$ & 0.009 & 0.14 & 160 & 3.3049 & 3.3049 \\
\hline $19 \mathrm{~A}$ & 0.014 & 0.21 & 218 & 3.3035 & -- \\
\hline $13 A$ & 0.049 & 0.73 & 196 & 3.3035 & 3.3049 \\
\hline $18 \mathrm{~A}$ & $-\infty$ & 3.63 & $148-480^{(a)}$ & -- & -- \\
\hline $18 \mathrm{~B}$ & -- & 3.63 & $1180-2900$ (b) & $\ldots$ & - \\
\hline
\end{tabular}

(a) Core of tantalum plus TaC.

(b) Case of $\mathrm{Ta}_{2} \mathrm{C}$. 
treated as described above without an intentional addition and reanalyzed for oxygen, nitrogen, and carbon. No significant changes were found in the nitrogen or carbon contents, however, the oxygen content increased from 12 to $100 \mathrm{ppm}$ during the heat treatments.

\section{X-Ray Diffraction Studies}

Because of the high-temperature heat treatments required in the present investigations, very large grains were produced in all the alloys studied. Therefore, special $\mathrm{X}$-ray diffraction techniques were employed. Sliver specimens were cut from each sample adjacent to the areas used for the chemical assay and the metallographic examination. These sliver specimens were ground to a fine needle point and the worked surface removed by electropolishing. Diffraction patterns were obtained with a $114.6-\mathrm{mm}$ camera with unfiltered copper radiation. Under these conditions nine diffraction lines were obtained at Bragg angles $(\theta)$ of over $65 \mathrm{deg}$. The (330) reflection occurred at approximately $83 \mathrm{deg}$ and provided the maximum sensitivity to lattice-parameter changes. The lattice parameter for each specimen was established by a linear extrapolation of the observations to a $\theta$ angle of $90 \mathrm{deg}$. Results of lattice-parameter determinations for the various alloys and annealing treatments are given in Tables 2, 3, and 4. The precision of these determinations is $\pm 0.0005 \mathrm{~A}$ or better based upon the spread of the observations.

Based upon these lattice-parameter determinations the solid-solubility limits of oxygen, nitrogen, and carbon in tantalum it 1500,1000 , and $500 \mathrm{C}$ were established by graphical methods as shown in Figures 1, 2, and 3, respectively. The solid solubility of oxygen in tantalum, as shown in Figure 1, was established at 3.65 a/o at $1500 \mathrm{C}$, $2.95 \mathrm{a} / 0$ at $1000 \mathrm{C}$, and $2.5 \mathrm{a} / 0$ at $500 \mathrm{C}$. Solid solubilities in the tantalum-nitrogen system, Figure 2, were found to be $3.70,2.75$, and $1.8 \mathrm{a} / 0$ at 1500,1000 , and $500 \mathrm{C}$, respectively. The solubility of carbon in tantalum was found to be very low, of the order of 0.1 a $/ 0$ at $1500 \mathrm{C}$ with no significant change in lattice parameter after annealing at $1000 \mathrm{C}$. No studies of the tantalum-carbon system were carried out on specimens annealed at $500 \mathrm{C}$.

\section{Metallog raphic Investigations}

Metallographic studies were made on all specimens described in Tables 2, 3, and 4; the portion examined being adjacent to that used for the X-ray diffraction analysis. Specimens were mounted in Bakelite, abraded on 240-, 400-, and 600-grit abrasive papers, then metallographically polished on wax laps using Linde A polishing agent dispersed in a chromic acid-water solution. A chemical polish in a solution containing $30 \mathrm{ml}$ lactic, $10 \mathrm{ml}$ of nitric acid plus $10 \mathrm{ml}$ of hydrofluoric acid was employed to remove the worked surface. After the chemical polish, the specimens were electroetched in $90 \mathrm{ml}$ sulfuric acid plus $10 \mathrm{ml}$ hydrofluoric acid at $0.02 \mathrm{amp}$ per $\mathrm{cm}^{2}$ to reveal the grain boundaries and the precipitate phases.

Included in the metallographic investigation were measurements of Knoop hardness on the $1500 \mathrm{C}$ annealed specimens (see Tables 2, 3, and 4). The hardness is seen to increase linearly with interstitial content for the tantalum-oxygen and the tantalum-nitrogen 


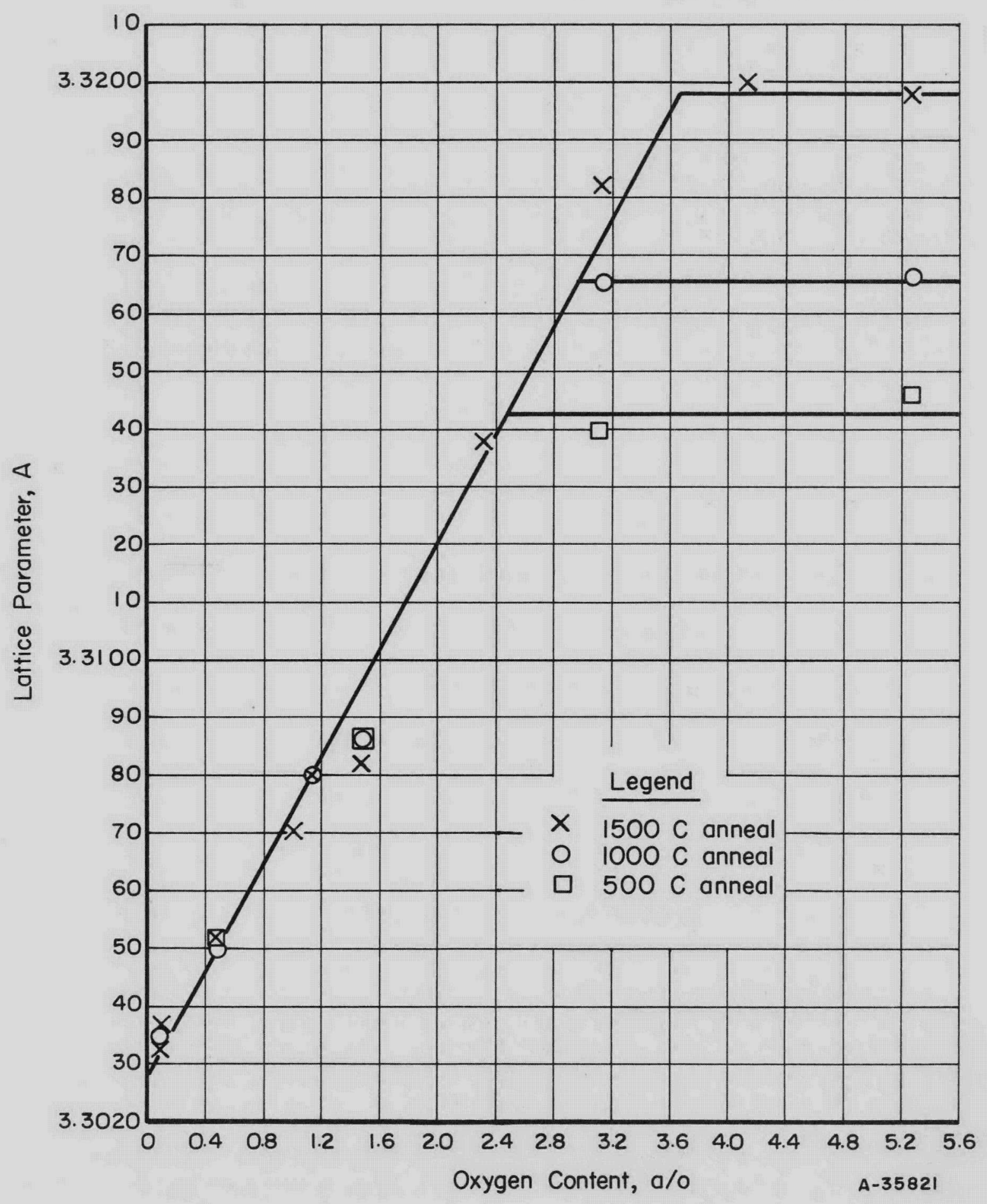

FIGURE 1. LATTICE-PARAMETER CHANGES IN TANTALUM WITH INCREASING OXYGEN CONTENT 


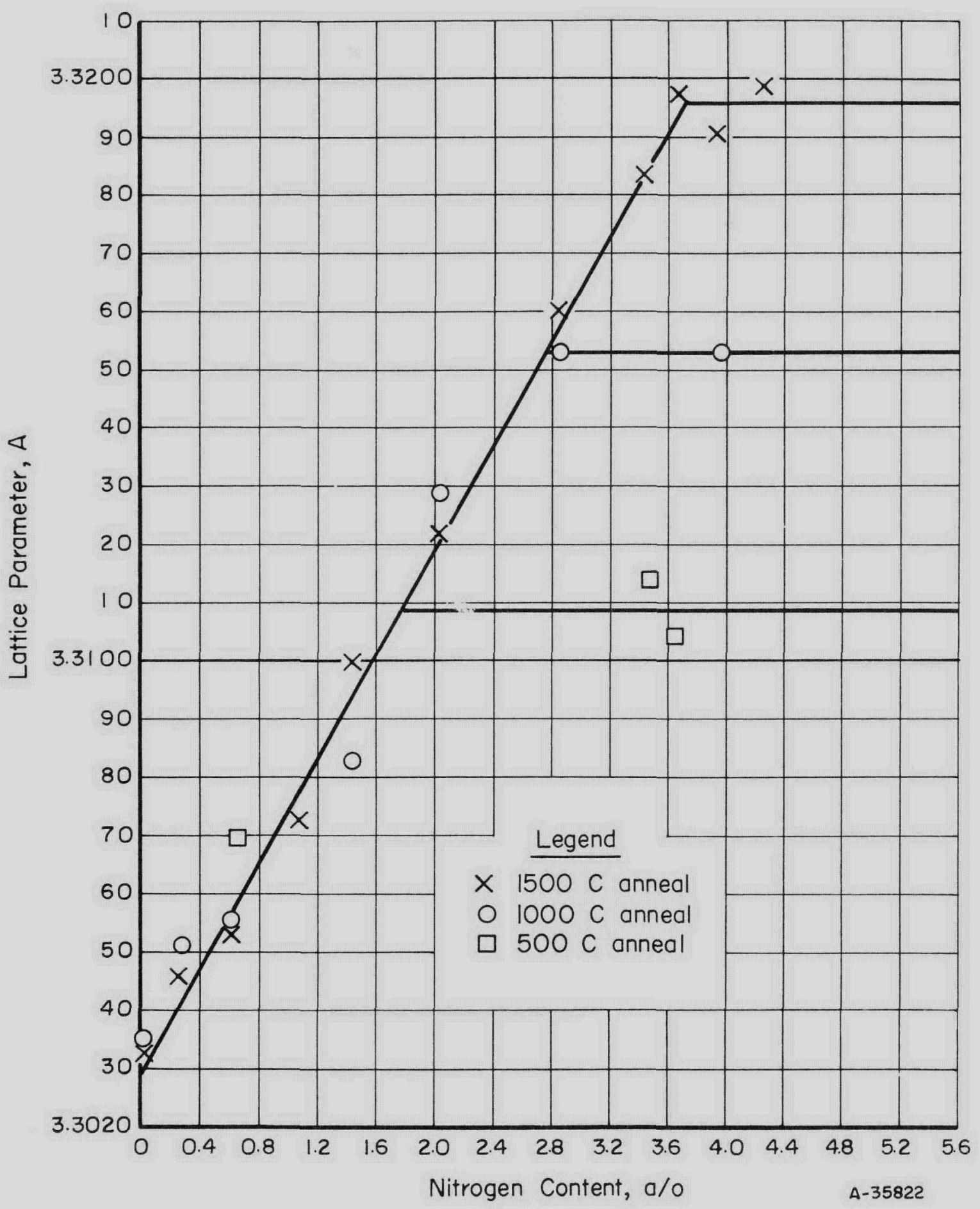

FIGURE 2. LATTICE-PARAMETER CHANGES IN TANTALUM WITH INCREASING NITROGEN CONTENT 




FIGURE 3. LAT TICE-PARAMETER CHANGES IN TANTALUM WITH INCREASING CARBON CONTENT 


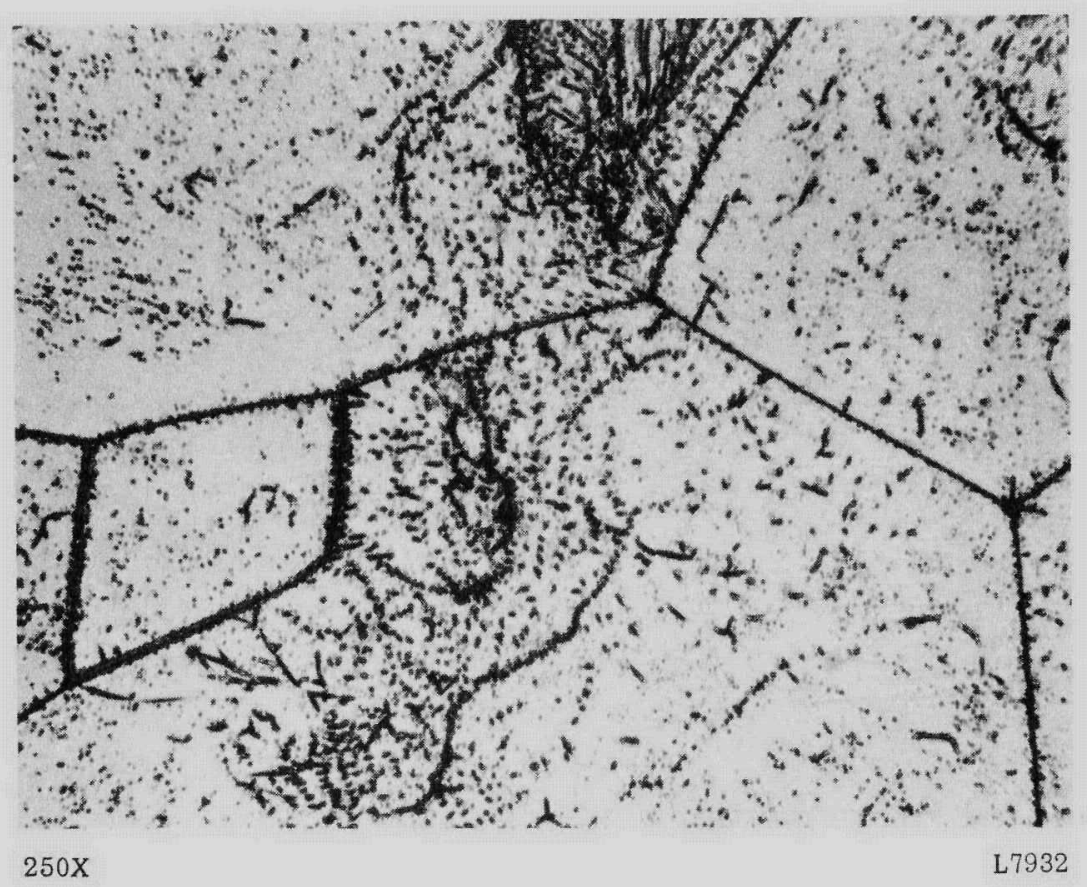

a. Specimen $2 \mathrm{~A}$, Rolled and Annealed $3 \mathrm{Hr}$ at $1500 \mathrm{C}$

b. Specimen $22 \mathrm{~A}$, Rolled and Homogenized $3 \mathrm{Hr}$ at $1800 \mathrm{C}$ and Annealed $3 \mathrm{Hr}$ at $1500 \mathrm{C}$

FIGURE 4. PHOTOMICROGRAPHS OF HIGH-PURITY TANTALUM 


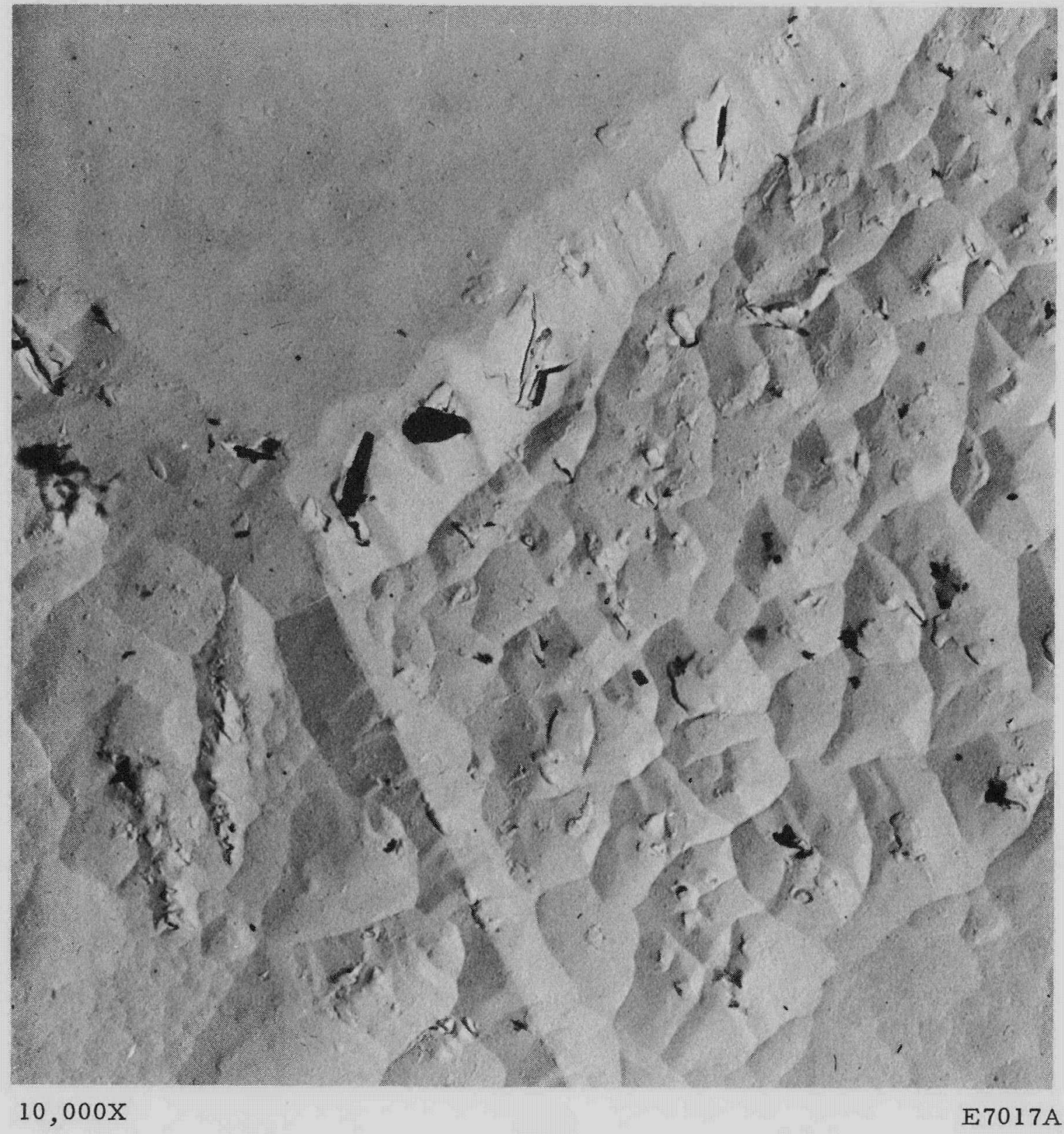

a. Negative Replica of Specimen 2A, Rolled and Annealed at $1500 \mathrm{C}$

FIGURE 5. ELECTRON MICROGRAPH OF HIGH-PURITY TANTALUM 


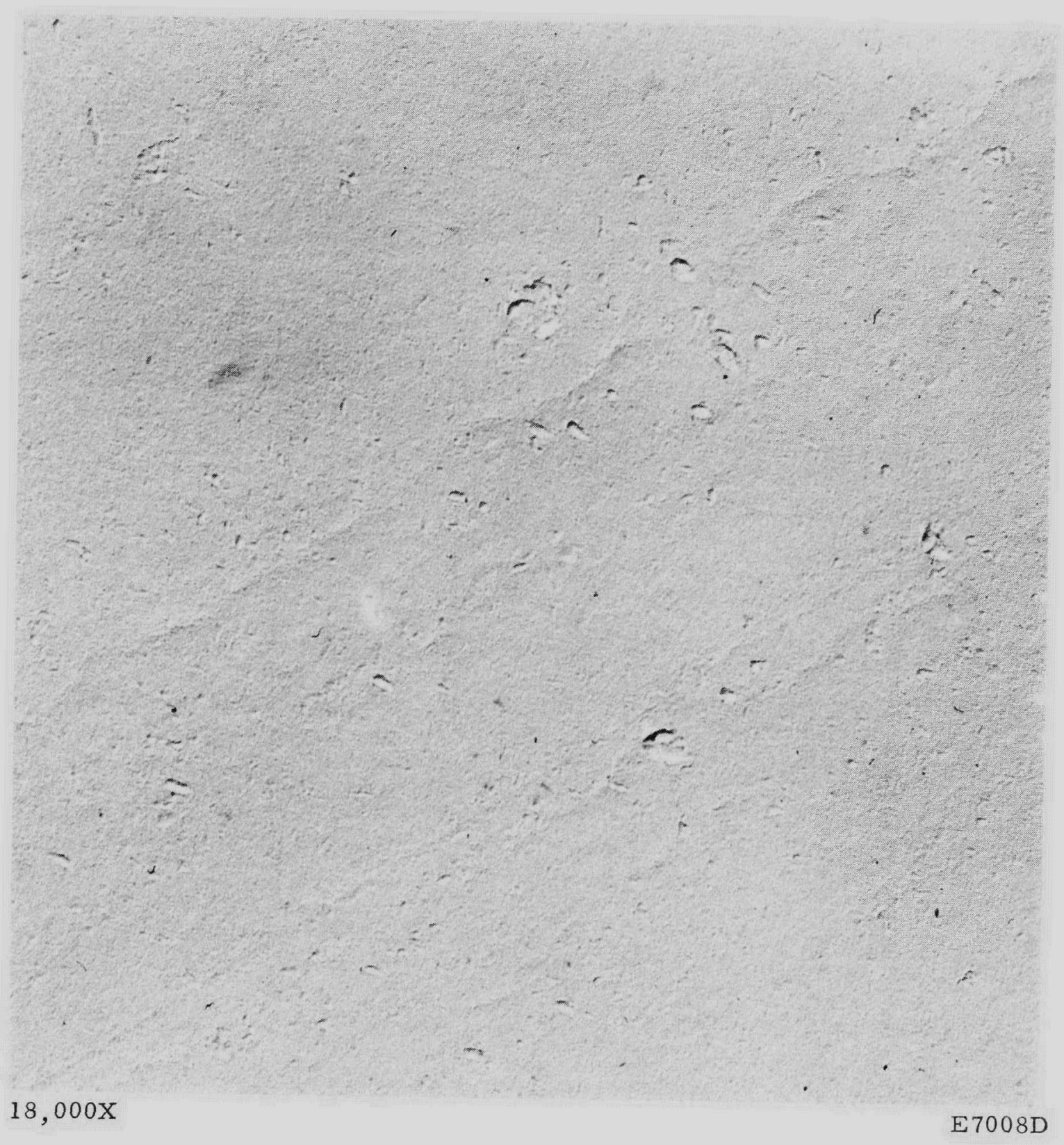

b. Negative Replica of Specimen 22A, Rolled, Heat Treated at $1800 \mathrm{C}$, and Annealed at $1500 \mathrm{C}$

FIGURE 5. (CONTINUED) 
specimens. There is, however, a significant difference in rate of increase, $125 \mathrm{KHN}$ per atom per cent oxygen and $200 \mathrm{KHN}$ per atom per cent nitrogen. It is quite likely that this difference is a result of the larger amounts of strain produced by nitrogen additions as discussed below.

In the case of nitrogen additions to tantalum, there is $\mathrm{X}$-ray evidence for lattice strain which was not observed in the oxygen or carbon alloys. The supersaturated nitrogen alloys gave broad diffraction lines at large diffracting angles for the matrix phase. This broadening is believed to be due to an epitaxial growth of the nitride phase on the tantalum matrix. The nitride phase has a pseudo structure with unit-cell size only slightly larger than that of the saturated solid solution but has a superlattice which is three times that of the pseudo cell.

In the case of carbon additions, the solubility was found to be very low and hence the hardness of the matrix metal was affected to a lesser degree than for tantalum-oxygen or tantalum-nitrogen alloys. Although the carbide phase is very hard (2900 KHN), a small addition of carbon, which produces a carbide phase $\left(\mathrm{Ta}_{2} \mathrm{C}\right)$ dispersed throughout the matrix, does not change the hardness of tantalum appreciably.

\section{High-Purity Tantalum}

The microstructures of high-purity tantalum specimens with no intentional addition but heat treated (1) at $1500 \mathrm{C}$, and (2) at $1800 \mathrm{C}$ followed by a $1500 \mathrm{C}$ anneal are of considerable interest because of the different etching behavior. This also provides a base structure for comparison with that obtained from the various interstitial alloys. Photomicrographs of the high-purity tantalum are shown in Figure 4. An intra- and intergranular etch attack is visible in Specimen 2A rolled and annealed at $1500 \mathrm{C}$ (Figure 4a) which does not show in Specimen 22A after an $1800 \mathrm{C}$ heat treatment followed by a $1500 \mathrm{C}$ anneal (Figure 4b). Although this etch attack has the appearance of a precipitate phase, the impurity content of the two specimens was not significantly different. The carbon and nitrogen contents were not changed by these heat treatments. Although the oxygen content was increased in both specimens from 12 to approximately $100 \mathrm{ppm}$, this is far below the solid-solubility limit and would not be expected to cause the difference in etching behavior.

Electron metallographic studies were made on these specimens. Figure $5 \mathrm{a}$ is an electron micrograph of Specimen 2A which was annealed at $1500 \mathrm{C}$ for $3 \mathrm{hr}$. Figure $5 \mathrm{~b}$ shows the structure at $18,000 \mathrm{X}$ for the specimen heated to $1800 \mathrm{C}$ then annealed at $1500 \mathrm{C}$. It is seen in Figure 5 a that etch pits occurred which revealed a subgrain structure. This is believed to be the result of an accumulation of dislocations and not evidence of a precipitate phase. In Figure 5b, the electron micrograph of tantalum annealed at $1800 \mathrm{C}$ and then $1500 \mathrm{C}$, there is a phase which is not attacked as rapidly as the matrix. This is believed to be a carbide phase which is discussed further in the next section. However, the subgrain structure as seen in Figure $5 \mathrm{a}$ is not evident here. This would suggest that the dislocations produced during rolling are not annealed out in $3 \mathrm{hr}$ at $1500 \mathrm{C}$ but are removed by a 3-hr $1800 \mathrm{C}$ heat treatment followed by an anneal at $1500 \mathrm{C}$. A study of the etching behavior of tantalum as a function of heat treatment plus transmission electron microscopy of tantalum would provide considerably more detail on the structural properties of this refractory metal and should be considered in an extension of these investigations. 
Tantalum-Carbon System

The solubility of carbon in tantalum was found to be less than could be determined accurately by lattice-parameter methods. There appeared to be a slight increase in lattice parameter over that of pure tantalum, but no significant change in lattice parameter with annealing temperature was detected. Metallographic examinations revealed no precipitate phase in Specimen $8 \mathrm{~A}$ (0.14 a/o carbon) when annealed at $1500 \mathrm{C}$, a trace of a precipitate phase in Specimen 19A (0.21 a/o carbon) and a large amount of precipitate in $13 \mathrm{~A}(0.73 \mathrm{a} / 0$ carbon). All three of these specimens contained a precipitate phase when annealed at $1000 \mathrm{C}$. Photomicrographs of the tantalum-carbon specimens are shown in Figures 6 and 7. Based upon the present metallographic and X-ray studies, it was concluded that the solid solubility of carbon in tantalum is $0.17 \mathrm{a} / \mathrm{o}$ at $1500 \mathrm{C}$ and is of the order of $0.07 \mathrm{a} / 0$ at $1000 \mathrm{C}$. Since $0.07 \mathrm{a} / 0$ carbon (content of the as-received tantalum) was the lowest carbon content available, no $500 \mathrm{C}$ anneals were carried out on specimens of the tantalum-carbon system.

The identification of the precipitate phase was incomplete, in that the pure phase has not been prepared, but the X-ray data have been compared with published structures for specific tantalum-carbon compounds. In the present studies of tantalum-carbon specimens, only one compound $\left(\mathrm{Ta}_{2} \mathrm{C}\right)$ has been observed. X-ray data for this phase are presented in Table 5. This pattern was obtained from Specimen 13B (Figure 7c), and from the carburized surface of Specimen 18B to which 3.6 a/o carbon was added. The white phase in Specimen 13B (Figure 7c) is $\mathrm{Ta}_{2} \mathrm{C}$. The fine structure seen in the matrix of this specimen and in Specimen 13A (Figure 6c) is due to crystallographic etch pitting. When these specimens were examined at higher magnification the carbide phase could be readily distinguished. Figure 8, an electron micrograph of Specimen 13A, shows the crystallographic attack by the etch plus the carbide particles. The carbide has round and oblong shapes. These fine carbide particles are not attacked by the etch and have the same appearance as the larger particles which gave the $\mathrm{Ta}_{2} \mathrm{C}$ pattern by $\mathrm{X}$-ray diffraction. Similar but fewer particles were seen in the electron micrograph of the high-purity tantalum which contained 0.07 a/o carbon.

\section{$\underline{\text { Tantalum-Nitrogen System }}$}

Photomicrographs of tantalum-nitrogen specimens annealed at $1500 \mathrm{C}$ are shown in Figure 9. An electron micrograph of a supersaturated specimen (36A) is shown in Figure 10. Based upon metallographic studies of these and other tantalum-nitrogen compositions which were annealed at $1500 \mathrm{C}$, the solid-solubility limit of $3.70 \mathrm{a} / 0 \mathrm{as}$ obtained by X-ray diffraction methods was confirmed. However, the precipitate was not readily distinguished by optical or electron microscopical methods. In Figure 10 the long row of grains is believed to be the $\operatorname{Tax}_{\mathrm{X}} \mathrm{N}$ phase. The small white phase dispersed throughout the matrix is believed to be $\mathrm{Ta}_{2} \mathrm{C}$ as previously described. At higher nitrogen contents ( 6.0 and $7.6 \mathrm{a} / \mathrm{o})$, Specimens $40 \mathrm{~A}$ and $41 \mathrm{~A}$ of Table 3 , the X-ray diffraction pattern of the nitride phase was observed. The $\mathrm{X}$-ray data for the nitride phase are given in Table 5. Its structure appears to be closely related to that of the body-centeredcubic tantalum, but additional diffraction lines are observed which require a unit cell for the nitride phase slightly more than three times that of tantalum. The diffraction pattern of the tantalum matrix phase in the specimen supersaturated with nitrogen is very broad in the back-reflection lines, and lattice parameters of the solid solution could not be obtained for the high-nitrogen specimens. The nitride phase, however, gave a sharp diffraction pattern. This suggests epitaxial growth of nitride on the tantalum matrix resulting in large amounts of strain in the tantalum lattice. 


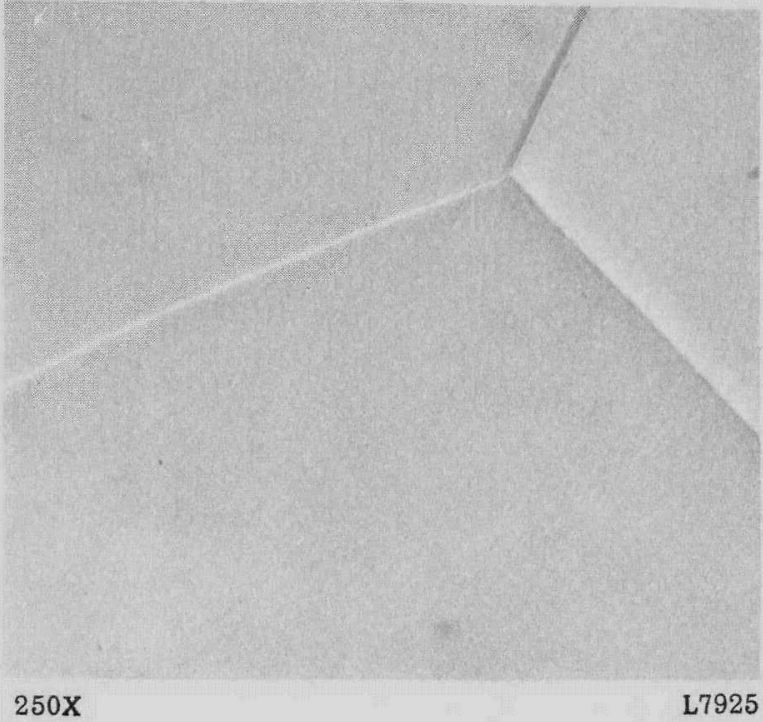

a. Specimen $8 \mathrm{~A}, 0.14 \mathrm{a} / 0$ Carbon

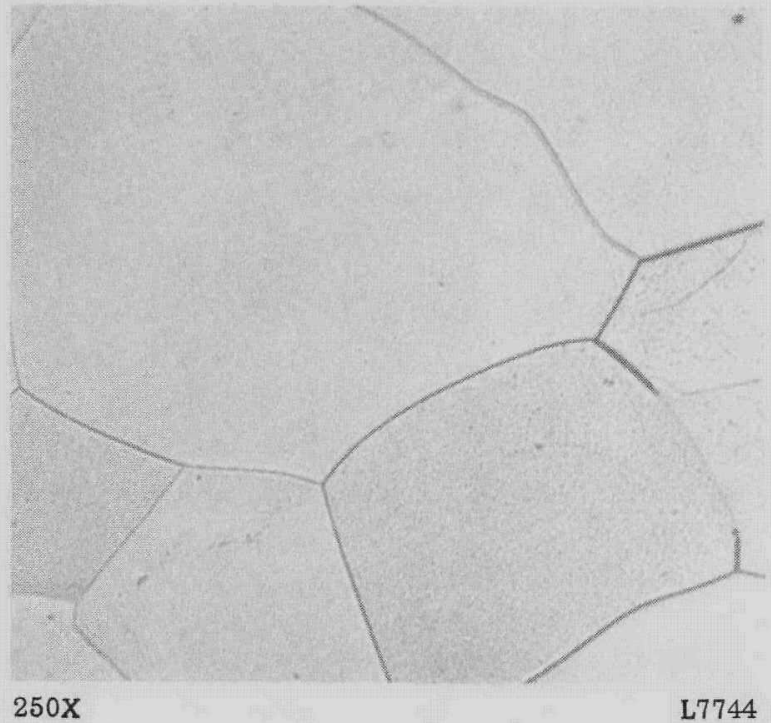

b. Specimen $19 \mathrm{~A}, 0.21$ a/o Carbon

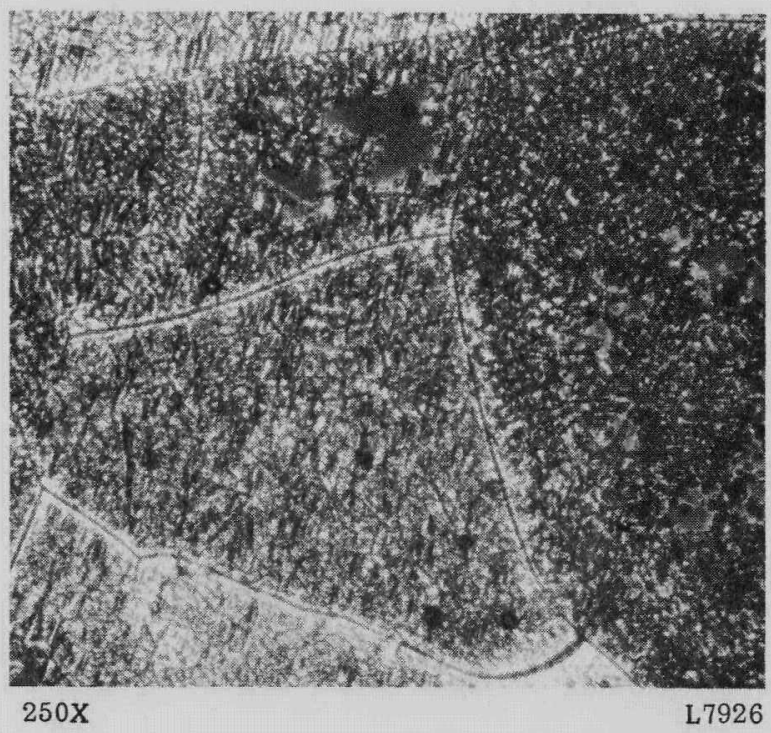

c. Specimen $13 \mathrm{~A}, 0.73$ a/o Carbon

FIGURE 6. PHOTOMICROGRAPH OF TANTALUM-CARBON SPECIMENS ANNEALED AT $1500 \mathrm{C}$ 


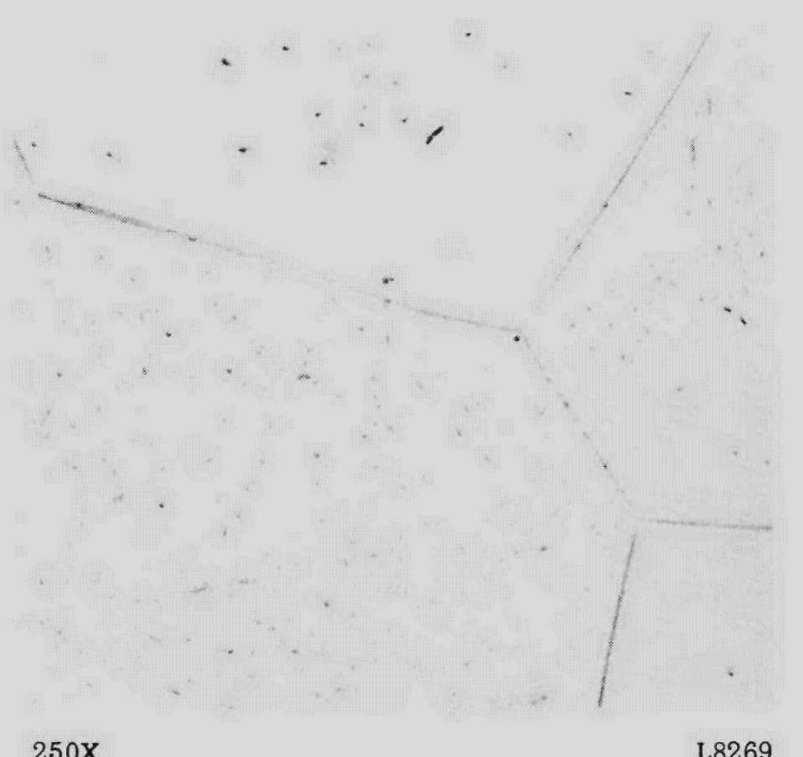

$250 \mathrm{X}$

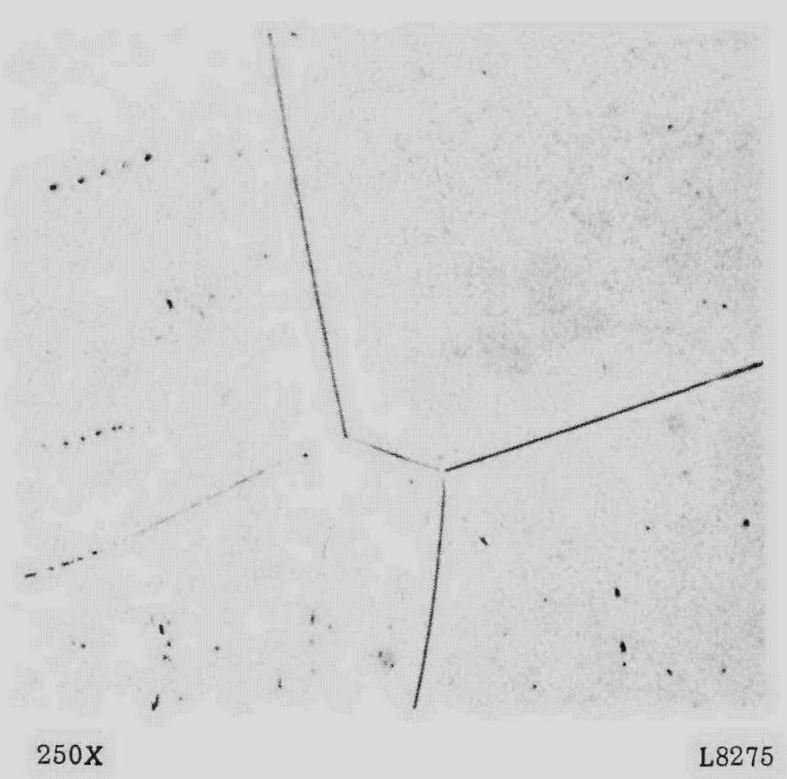

b. Specimen 19B, 0.21 a/o Carbon

a. Specimen $8 \mathrm{~B}, 0.14 \mathrm{a} / \mathrm{o}$ Carbon

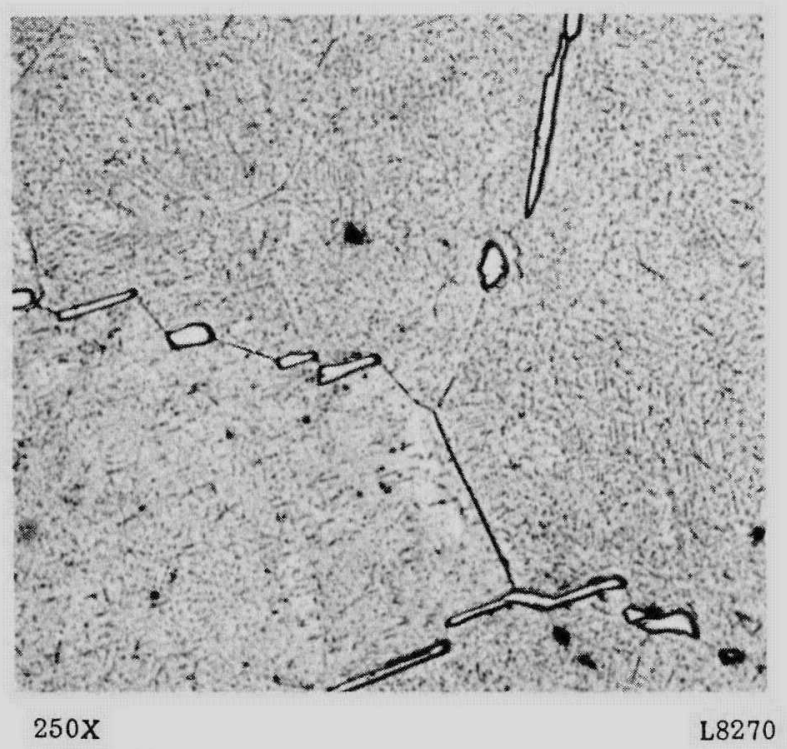

c. Specimen $13 \mathrm{~B}, 0.73 \mathrm{a} / \mathrm{o}$ Carbon

FIGURE 7. PHOTOMICROGRAPHS OF TANTALUM-CARBON SPECIMENS ANNEALED AT $1000 \mathrm{C}$ 
TABLE 5. X-RAY DIFFRACTION PATTERNS OF THE PRECIPITATE PHASES IN SUPERSATURATED TANTALUM-CARBON, TANTALUM-NITROGEN, AND TANTALUM-OXYGEN ALLOYS

Filtered Iron Radiation

\begin{tabular}{|c|c|c|c|c|c|c|c|c|}
\hline \multicolumn{3}{|c|}{ Tantalum-Carbon $(\mathrm{a})$} & \multicolumn{3}{|c|}{ Tantalum-Nitrogen $(\mathrm{b})$} & \multicolumn{3}{|c|}{ Tantalum-Oxygen $(\mathrm{c})$} \\
\hline $\begin{array}{c}\text { Interplanar } \\
\text { Spacing, } \\
\text { A }\end{array}$ & $\begin{array}{c}\text { Miller } \\
\text { Indices, } \\
\text { hk } \ell\end{array}$ & $\begin{array}{c}\text { Relative } \\
\text { Intensity, } \\
\text { Visual }\end{array}$ & $\begin{array}{c}\text { Interplanar } \\
\text { Spacing, } \\
\text { A }\end{array}$ & $\begin{array}{l}\text { Miller } \\
\text { Indices, } \\
\text { hk } \ell\end{array}$ & $\begin{array}{c}\text { Relative } \\
\text { Intensity, } \\
\text { Visual }\end{array}$ & $\begin{array}{c}\text { Interplanar } \\
\text { Spacing, } \\
\text { A }\end{array}$ & $\begin{array}{c}\text { Miller } \\
\text { Indices, } \\
\text { hk } b\end{array}$ & $\begin{array}{c}\text { Relative } \\
\text { Intensity, } \\
\text { Visual }\end{array}$ \\
\hline 2.68 & 100 & 30 & 2.37 & 330 & 100 & 3.87 & 001 & 100 \\
\hline 2. 46 & 002 & 50 & 2. 26 & 420 & 30 & 3. 14 & 110 & 90 \\
\hline 2.36 & 101 & 100 & 1.98 & 510 & 40 & 3.09 & 200 & 40 \\
\hline 1.82 & 102 & 30 & 1.68 & 600 & 50 & 2. 44 & $111+201$ & 90 \\
\hline 1.31 & 112 & 30 & 1.28 & 732 & 30 & 1. 94 & 002 & 30 \\
\hline 1.29 & 201 & 30 & 1. 24 & 811 & 20 & 1.83 & 020 & 25 \\
\hline 1.23 & 004 & 10 & 1. 18 & 660 & 40 & 1.80 & 310 & 15 \\
\hline 1. 18 & 202 & 10 & 1. 13 & 840 & 10 & 1.65 & 021 & 70 \\
\hline 1. 12 & $\left\{\begin{array}{l}104 \\
113\end{array}\right.$ & 10 & 1.11 & 910 & 10 & 1. 57 & 220 & 10 \\
\hline & $=$ & a & 0.970 & 666 & 50 & 1. 33 & 022 & 30 \\
\hline & & & & & & 1. 32 & 312 & 20 \\
\hline & & & & & & 1. 22 & 222 & 10 \\
\hline & & & & & & 1. 19 & 113 & 30 \\
\hline
\end{tabular}

(a) $\mathrm{Ta}_{2} \mathrm{C}$, hexagonal: $\mathrm{a}=3.10, \mathrm{c}=4.93$.

(b) $\mathrm{Ta}_{\mathrm{X}} \mathrm{N}$, complex cubic: $\mathrm{a}=10.09$.

(c) $\mathrm{Ta}_{2} \mathrm{O}_{5}$, orthorhombic: $\mathrm{a}=6.16, \mathrm{~b}=3.66, \mathrm{c}=3.87$. 


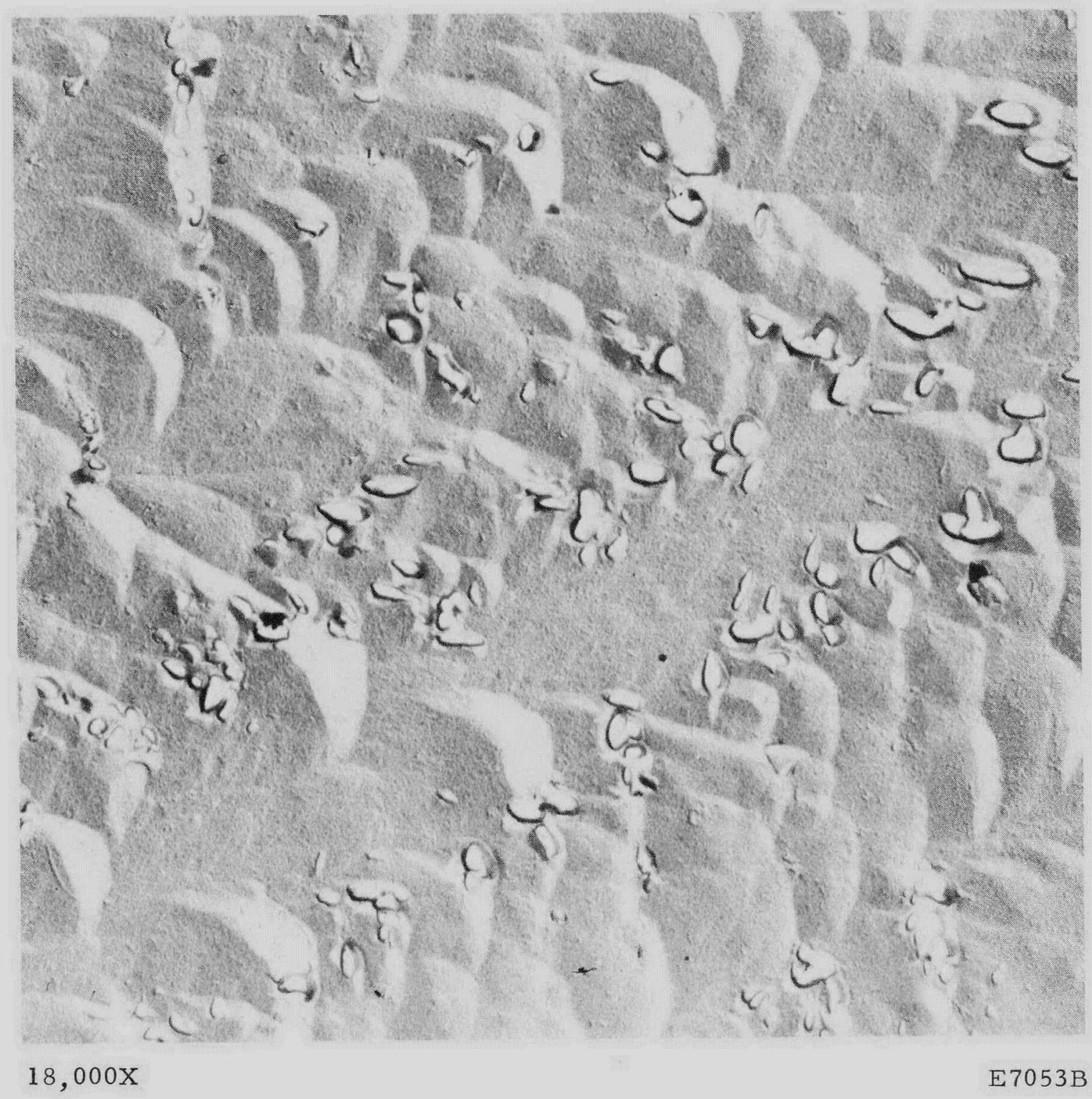

FIGURE 8. ELEC TRON MICROGRAPH OF TANTALUM-0.73 a/o CARBON SPECIMEN ANNEALED AT 1500 C

Negative replica of Specimen 13A is shown here. 


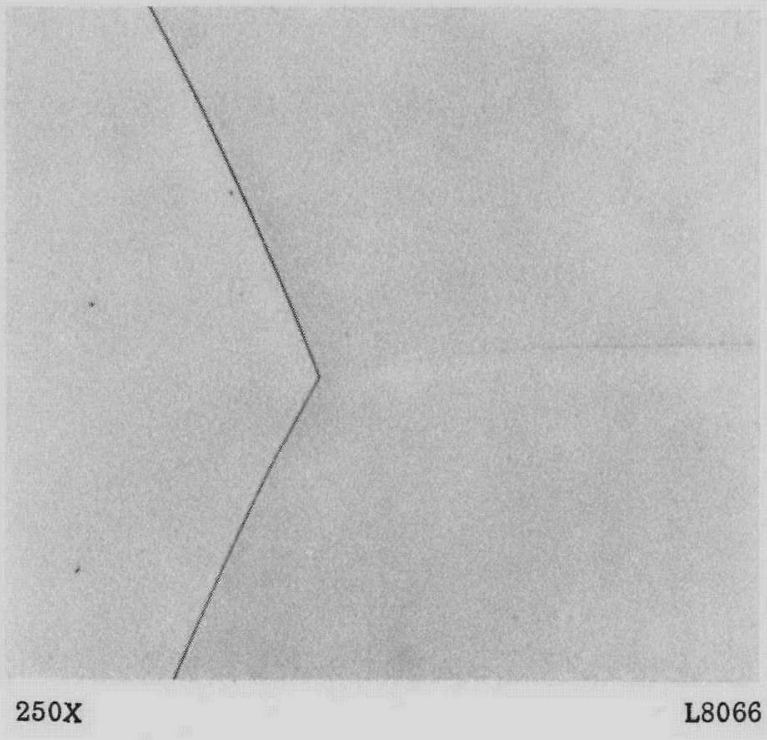

a. Specimen $30 \mathrm{~A}, 0.27 \mathrm{a} / 0$ Nitrogen

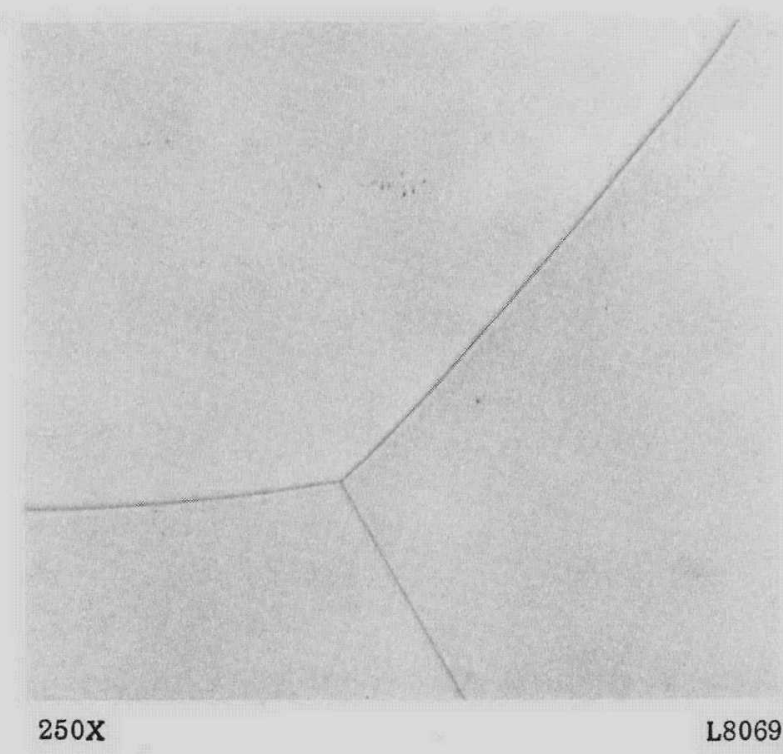

b. Specimen $32 \mathrm{~A}, 2.82 \mathrm{a} / \mathrm{o}$ Nitrogen

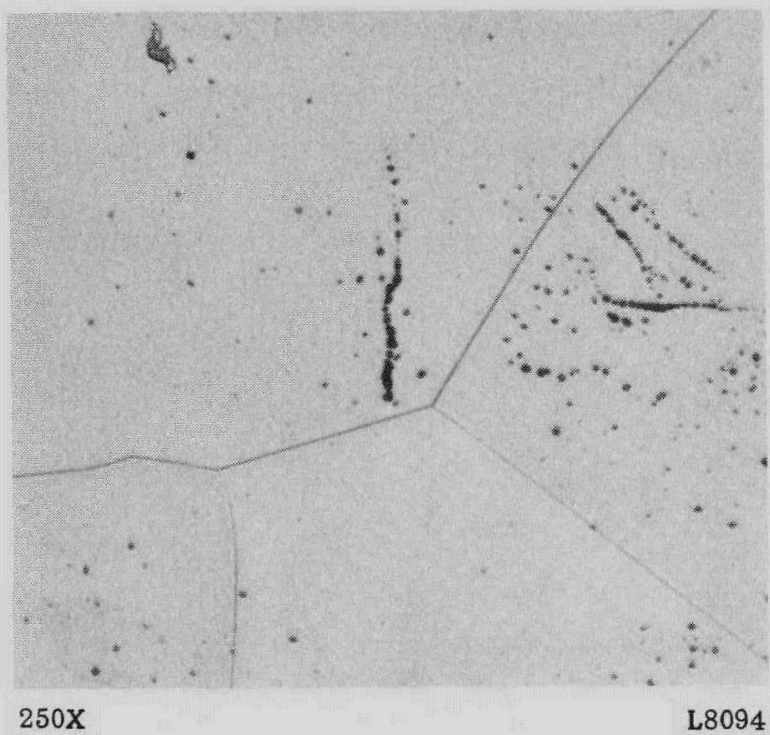

c. Specimen $36 \mathrm{~A}, 4.24 \mathrm{a} / \mathrm{o}$ Nitrogen

FIGURE 9. PHOTOMICROGRAPHS OF TANTALUM -NITROGEN SPECIMENS ANNEALED AT $1500 \mathrm{C}$ 


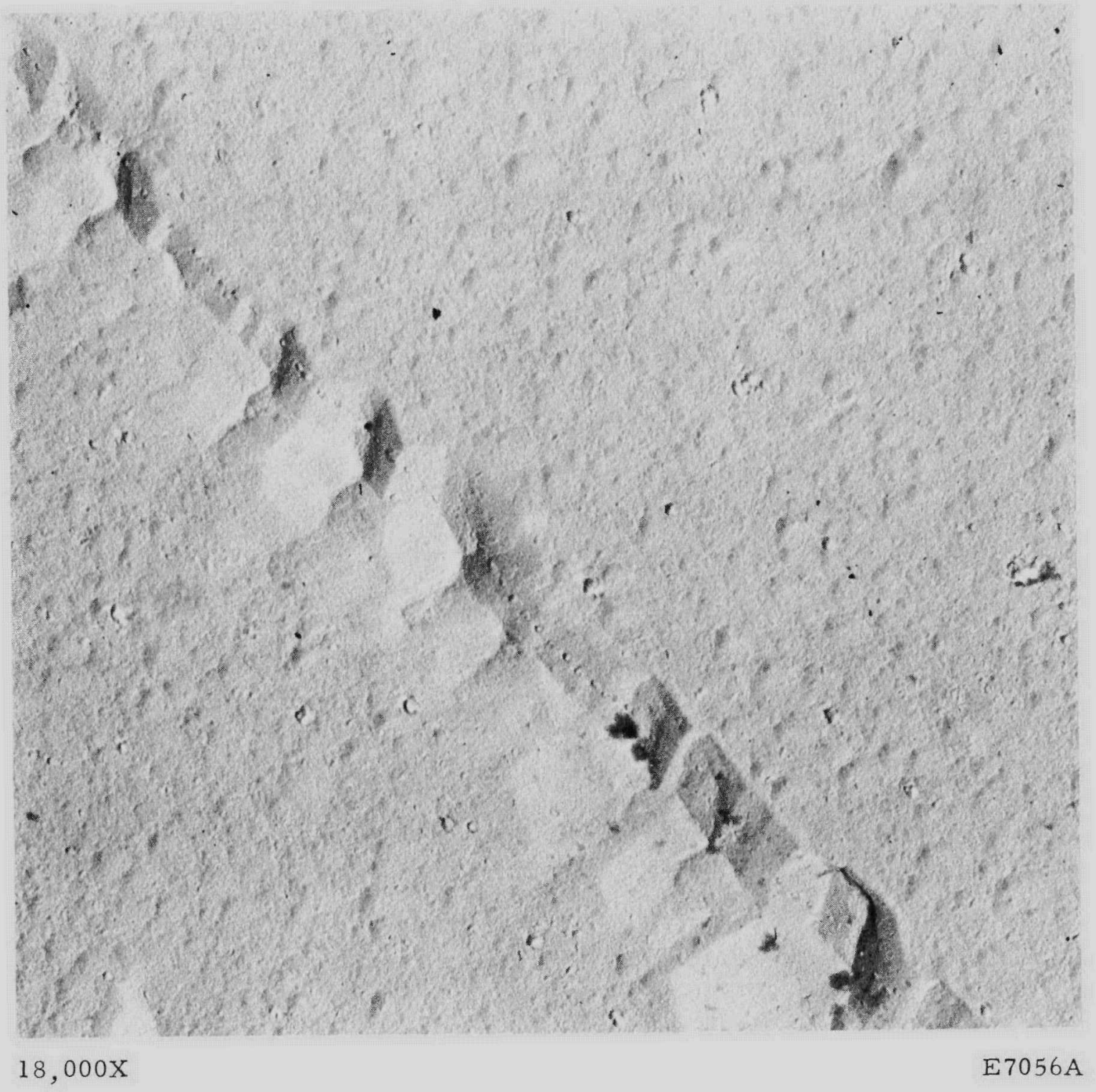

FIGURE 10. ELECTRON MICROGRAPH OF TANTALUM-4.24 a/o NITROGEN SPECIMEN ANNEALED AT $1500 \mathrm{C}$

Negative replica of Specimen $36 \mathrm{~A}$ is shown here. 
The solubility in the tantalum-nitrogen system at $1000 \mathrm{C}$ as determined by $\mathrm{X}$-ray diffraction was $2.75 \mathrm{a} / \mathrm{o}$. This is significantly lower than that obtained at $1500 \mathrm{C}$. Metallographically an etch pattern was observed in the 1000 and $500 \mathrm{C}$ annealed specimens which would have indicated a solubility of less than $0.27 \mathrm{a} / \mathrm{o}$. Photomicrog raphs of various tantalum-nitrogen specimens, annealed at 1000 and $500 \mathrm{C}$, are shown in Figure 11 and 12, respectively. It is evident that no change in the etching characteristic occurred with increasing nitrogen concentration which would coincide with the solubility limit as obtained by the $\mathrm{X}$-ray studies. The etch pits appear to outline subgrains with some pits occurring within the subgrain structure. At high nitrogen contents, a phase appears to be present within the pits (Specimen 33B). This phase could not be observed in the lownitrogen specimen when examined at 500X. Time did not permit an electron metallographic study of the specimen annealed at 1000 or $500 \mathrm{C}$. Thus, because of the severe etch pitting of the tantalum-nitrogen specimens after annealing at 1000 and $500 \mathrm{C}$, the $\mathrm{X}$-ray solid-solubility analyses of $2.75 \mathrm{a} / \mathrm{o}$ and $1.8 \mathrm{a} / \mathrm{o}$, respectively, are considered to be more reliable than the present metallographic determinations. The pitting characteristics of these tantalum-nitrogen specimens are believed to be due to an accumulation of lattice imperfections. These sites may provide nuclei for precipitation of the nitride phase in the supersaturated nitrogen alloys. This would account for appearance of the nitride phase in the same distribution as the etch pits. It is interesting to note that this etch pitting was found to be much more pronounced in the tantalum-nitrogen alloys than in the tantalum-oxygen specimens, and may be related to the difference in the amount of lattice strain, which in the nitrogen alloys, appears to have been caused by coherent precipitation.

\section{Tantalum-Oxygen System}

Photomicrographs of tantalum-oxygen specimens annealed at 1500, 1000, and $500 \mathrm{C}$ are shown in Figures 13, 14, and 15, respectively. The intragranular structure shows little or no preferential etching attack through the solid-solubility region. However, after a $500 \mathrm{C}$ anneal, the specimens were stained by etching techniques which did not stain the specimens annealed at 1500 or $1000 \mathrm{C}$. In the case of one $1000 \mathrm{C}$ annealed specimen (34B) an etch pit is seen (Figure 14c) which is similar to that observed for tantalum-nitrogen specimens. Since X-ray studies indicate Specimen $34 \mathrm{~B}$ to be supersaturated with oxygen, this may be the first form of the oxide precipitate. At supersaturated oxygen concentrations (Specimens 35A, 39A, 34C, and 35C of Figures $13 \mathrm{c}$ and $\mathrm{d}$ and $15 \mathrm{~b}$ and $\mathrm{c}$ ), however, a platelike precipitate forms which is oriented with respect to the saturated solid-solution matrix. The X-ray diffraction pattern as obtained from the platelike phase of Specimens $34 \mathrm{C}$ and 39A is given in Table 5. This pattern has been identified as the low-temperature allotropic modification of $\mathrm{Ta}_{2} \mathrm{O}_{5}$. In Specimens $35 \mathrm{~A}$, $B$, and $C$, a third phase consisting of spherical particles, is seen in the grain boundaries of the matrix and associated with the platelike precipitate. This phase has been identified as the high-temperature allotropic modification of $\mathrm{Ta}_{2} \mathrm{O}_{5}$. It is quite likely that the spherical oxide particles formed during the oxidation treatment but were not dissolved in the tantalum matrix during the $1800 \mathrm{C}$ homogenizing treatment. Based upon the presence of the latter oxide phase, it is likely that the solid solubility of oxygen in tantalum at $1800 \mathrm{C}$ is less than $5.27 \mathrm{a} / \mathrm{o}$.

The above metallographic studies are consistent with the $\mathrm{X}$-ray analyses of the solid solubility of oxygen in tantalum, namely, 3.65, 2.95, and 2.5 a/o at 1500,1000 , and $500 \mathrm{C}$, respectively. 


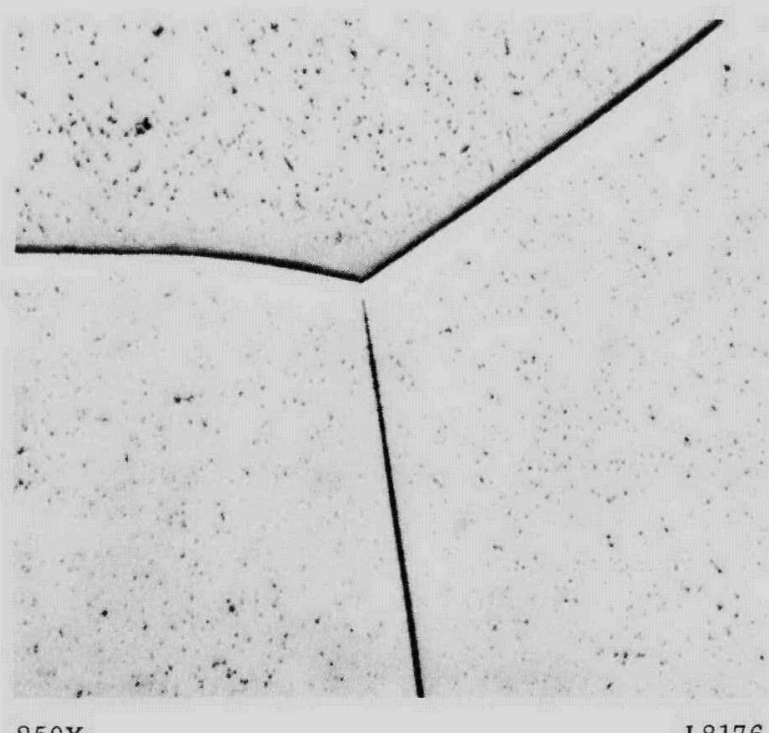

$250 \mathrm{X}$

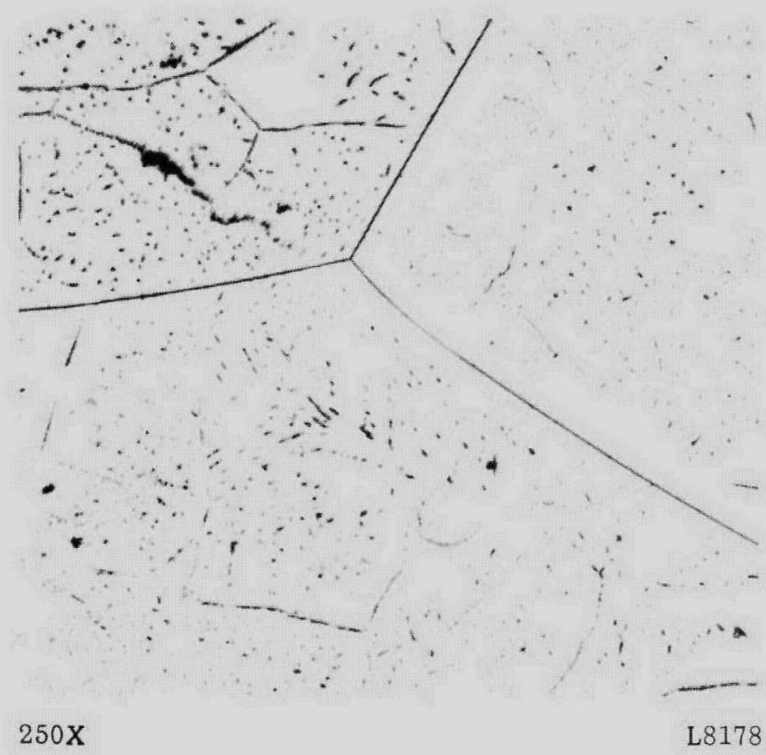

b. Specimen $31 \mathrm{~B}, 2.01$ a/o Nitrogen

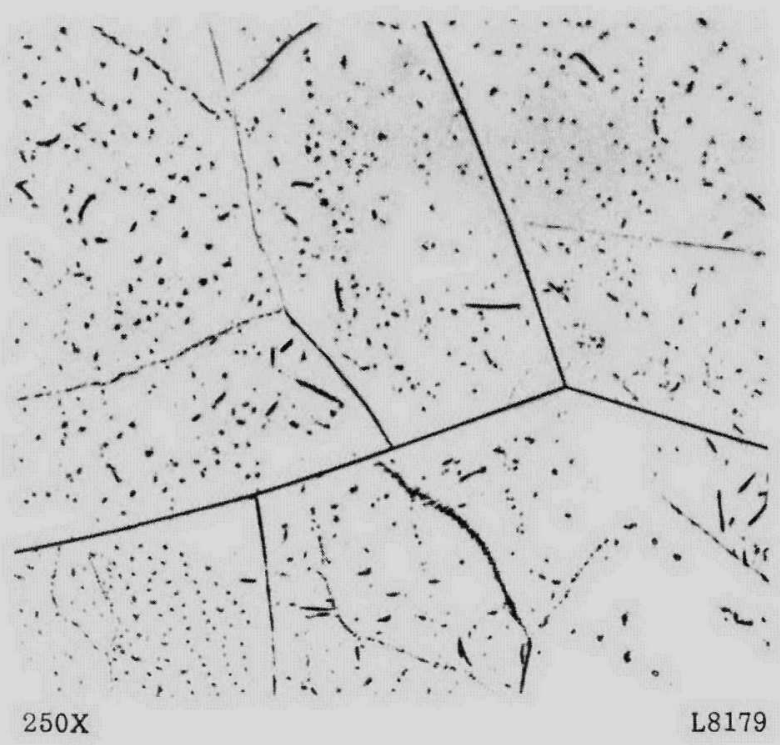

c. Specimen $32 \mathrm{~B}, 2.82 \mathrm{a} / \mathrm{o}$ Nitrogen

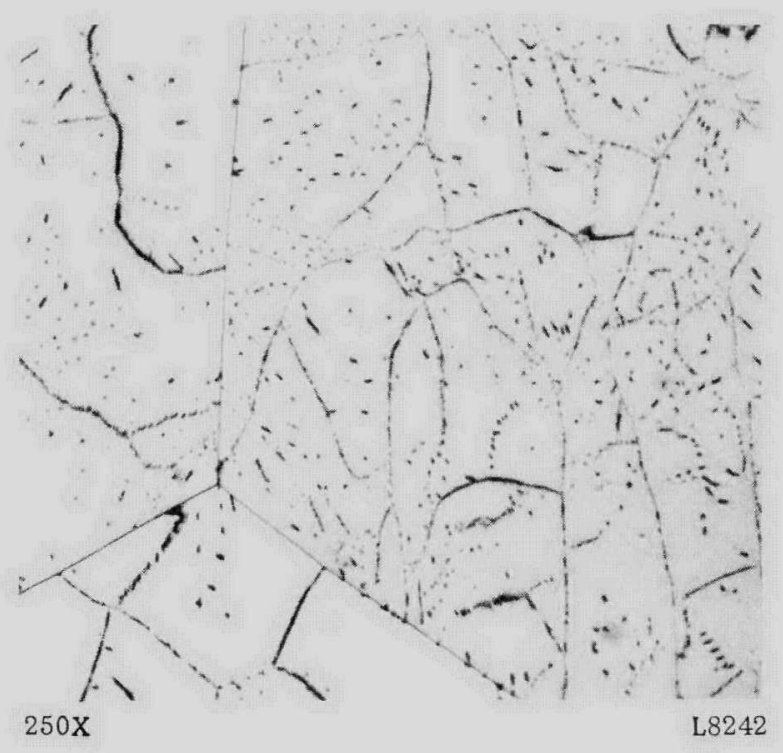

d. Specimen 33B, 3.99 a/o Nitrogen

FIGURE 11. PHOTOMICROGRA PHS OF TANTALUM-NITROGEN SPECIMENS ANNEALED AT $1000 \mathrm{C}$ 


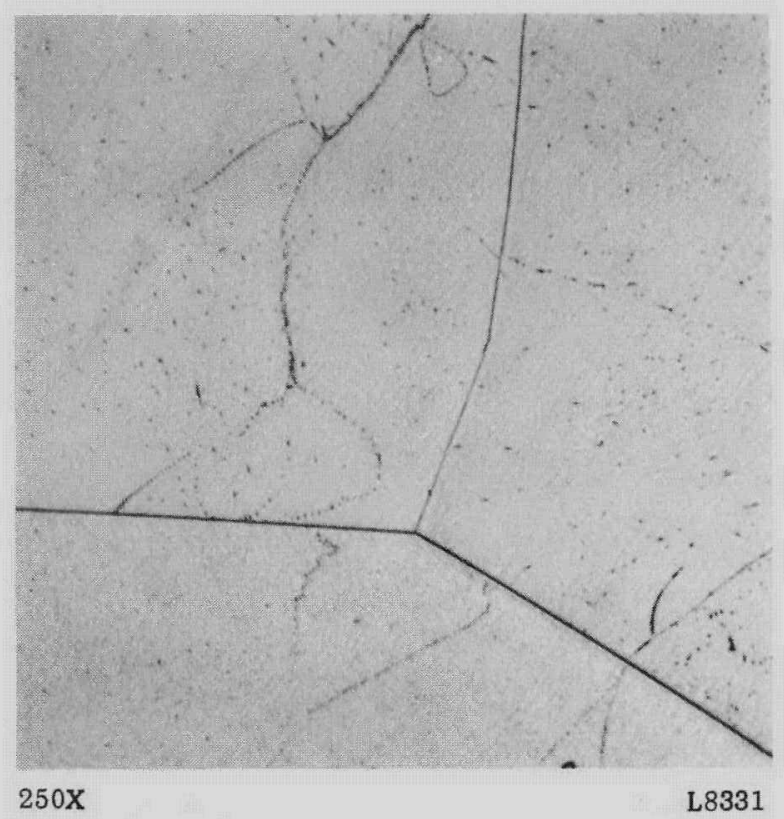

a. Specimen $23 \mathrm{C}, 0.63$ a/o Nitrogen

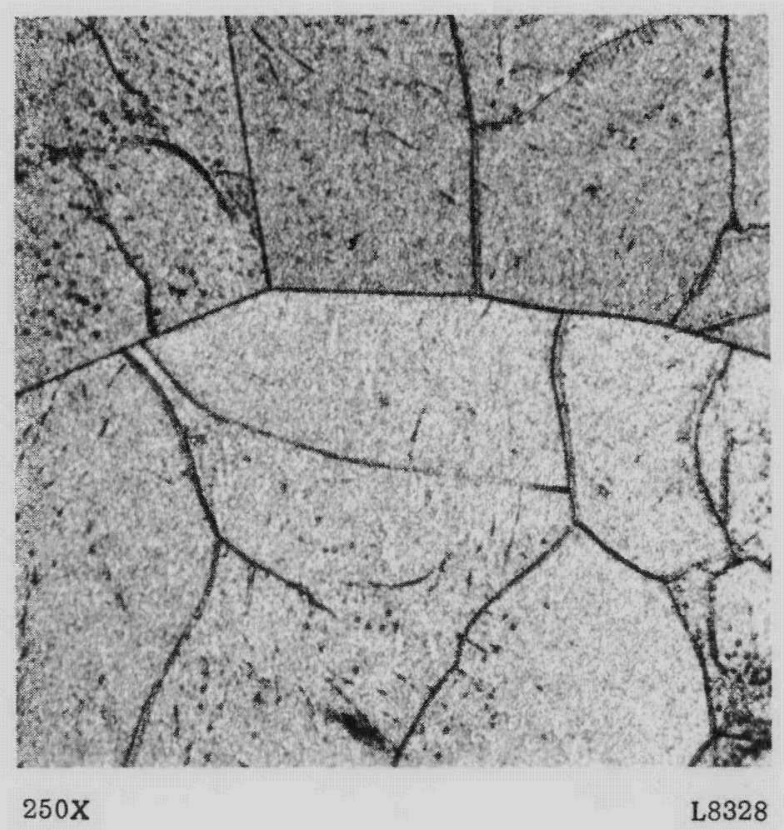

b. Specimen 20D, 3.42 a/o Nitrogen

FIGURE 12. PHOTOMICROGRAPHS OF TANTALUM-NITROGEN SPECIMENS ANNEALED A T $500 \mathrm{C}$ 


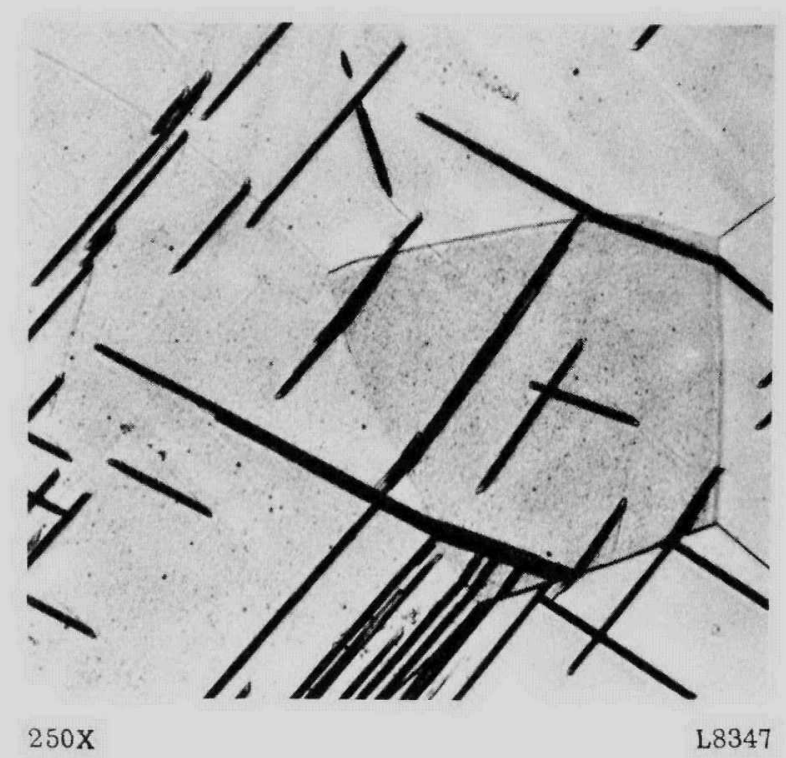

c. Specimen $39 \mathrm{~A}, 4.32$ a/o Oxygen

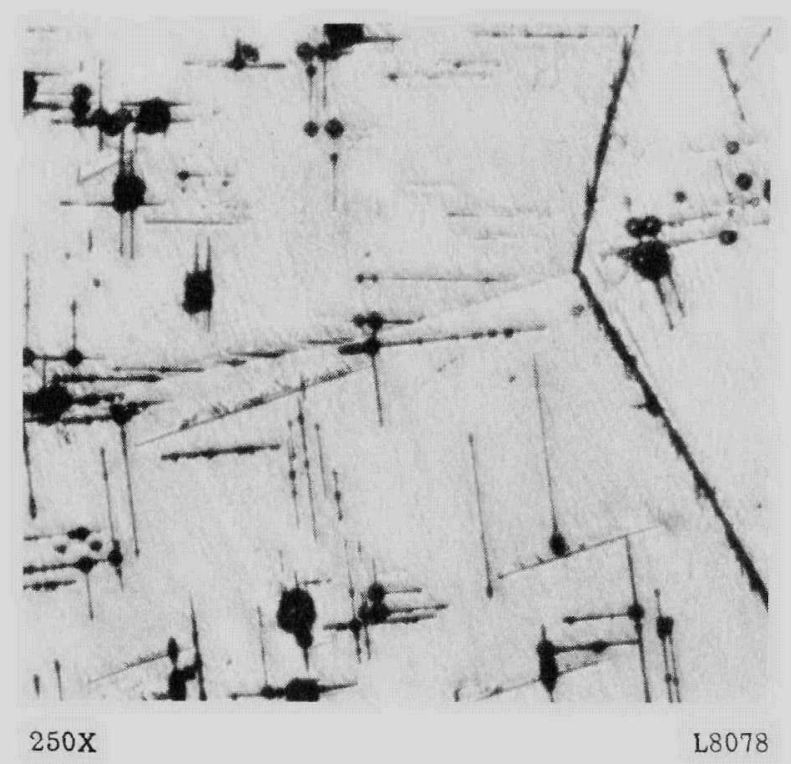

d. Specimen $35 \mathrm{~A}, 5.27$ a/o Oxygen

FIGURE 13. PHOTOMICROGRAPHS OF TANTALUM-OXYGEN SPECIMENS ANNEALED A T $1500 \mathrm{C}$ 


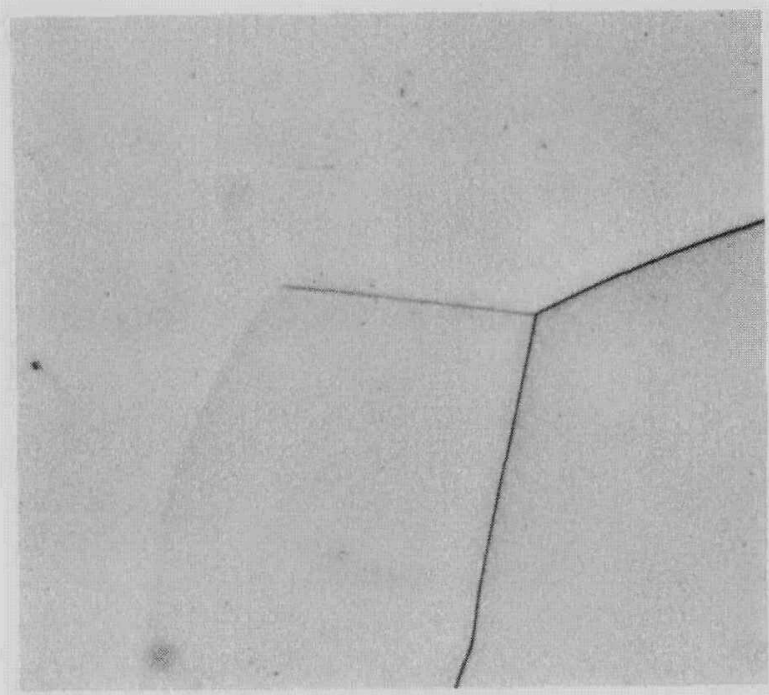

$250 \mathrm{X}$

$\mathbf{L} 8172$

a. Specimen 11B, 1.18 a/o Oxygen

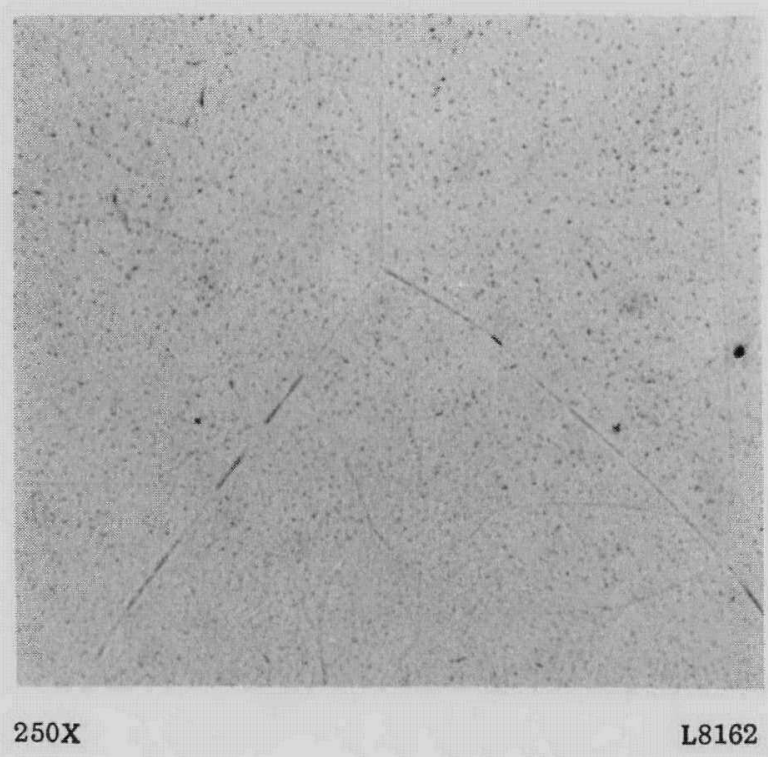

c. Specimen $34 \mathrm{~B}, 3.16$ a/o Oxygen

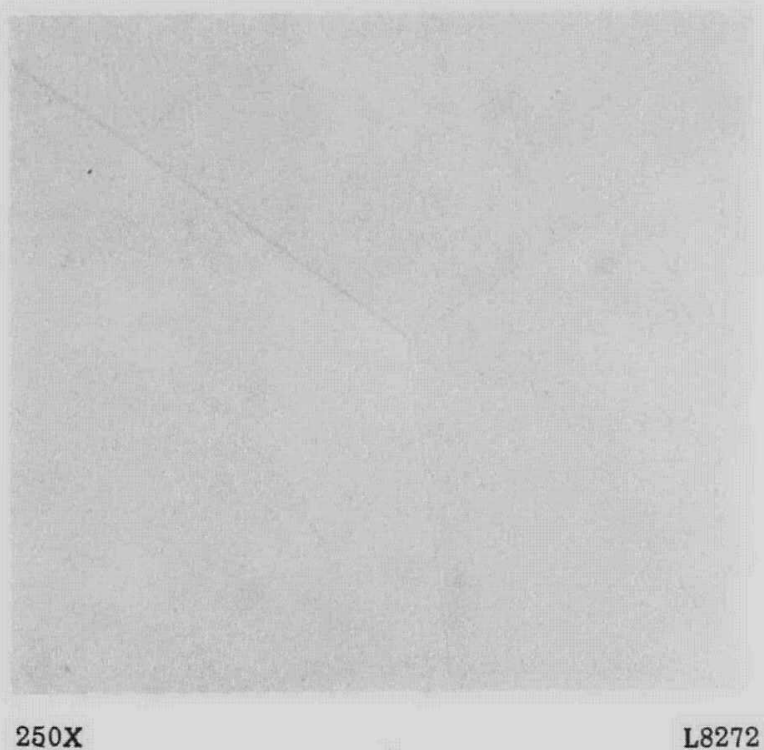

b. Specimen $15 \mathrm{~B}, 1.49$ a/o Oxygen

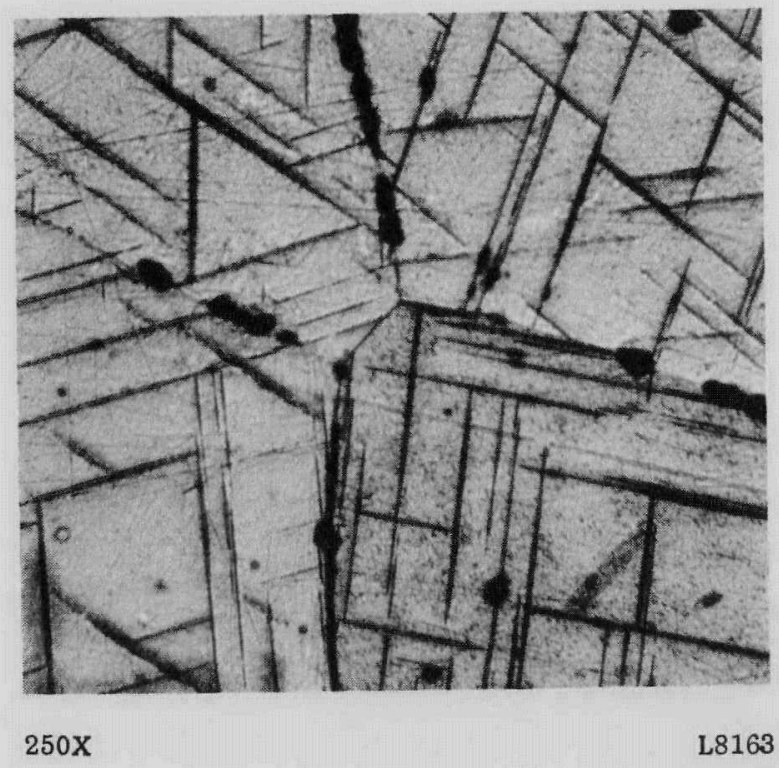

d. Specimen 35B, 5.27 a/o Oxygen

FIGURE 14. PHOTOMICROGRAPHS OF TANTALUM-OXYGEN SPECIMENS ANNEALED A T $1000 \mathrm{C}$ 


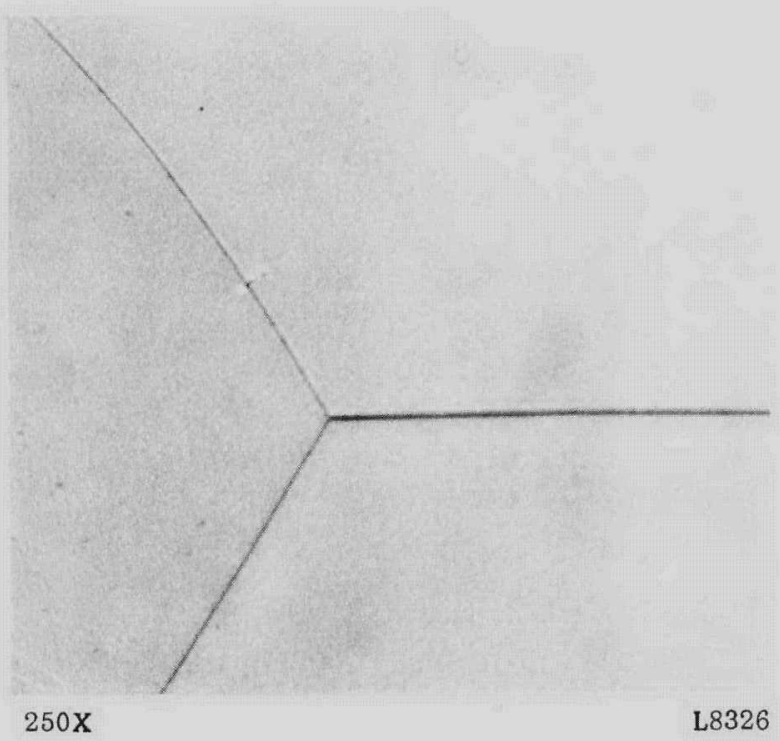

a. Specimen $15 \mathrm{C}, 1.49$ a/o Oxygen

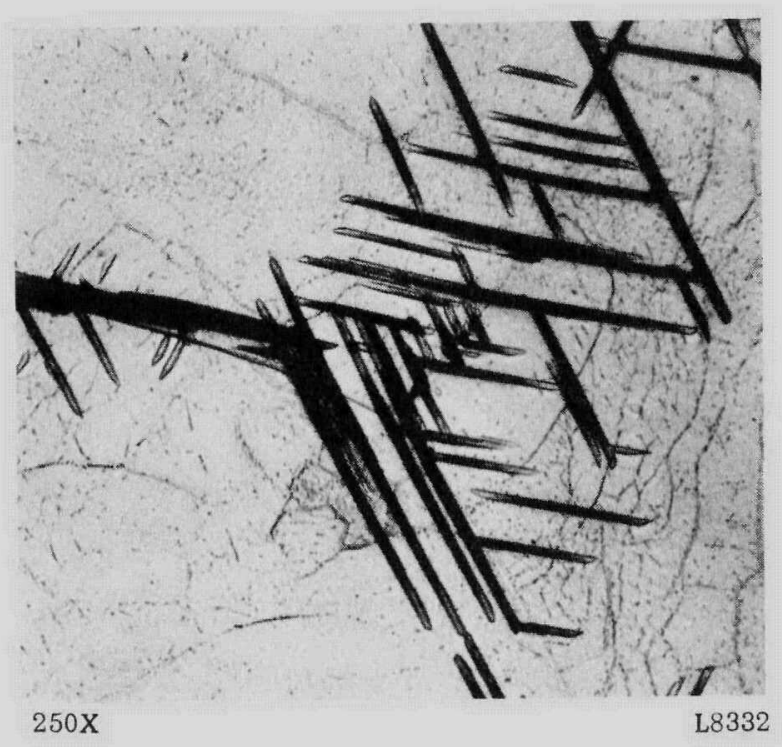

b. Specimen $34 \mathrm{C}, 3.16 \mathrm{a} / 0$ Oxygen



c. Specimen 35C, 5.27 a/o Oxygen

FIGURE 15. PHOTOMICROGRAPHS OF TANTALUM-OXYGEN SPECIMENS ANNEALED AT $500 \mathrm{C}$ 


\section{DISCUSSION OF RESULTS}

Of the interstitial elements carbon, nitrogen, and oxygen, the first is least soluble in tantalum. Although a precipitate, identified as $\mathrm{Ta}_{2} \mathrm{C}$, was detected by the present metallographic studies of high-purity tantalum, the etching behavior of the unalloyed metal has been attributed in part to other structural imperfections. These imperfections are modified by thermal treatments in which the known compositional factors would not be altered. Fabrication-type dislocations which concentrate in and near grain boundaries during heat treatment are believed to be responsible for this etching behavior. These imperfections may provide paths for rapid diffusion of the molten-plutonium fuel mixtures. Additional studies of these lattice imperfections are recommended. It is interesting to note, however, that the etch pitting seen in the high-purity tantalum specimen shown in Figure $4 \mathrm{a}$ was much less pronounced in the case of a 0.5 a/o oxygen alloy which was given the same $1500 \mathrm{C}$ anneal. This might suggest that an alloy low in oxygen would provide a satisfactory container material for the above-mentioned nuclear fuel. However, other factors would have to be considered before this could be recommended.

Oxygen impurity in tantalum would be the least likely, of the interstitials studied, to form a precipitate phase. The oxygen solubility limit, 3.65 a/o at $1500 \mathrm{C}$, as established in the present studies is in good agreement with that reported by Gebhardt(2). However, at lower temperatures, the present studies show somewhat greater oxygen solubility than he reported. These differences cannot be explained, but may indicate that additional low-temperature investigations should be made. Although a number of oxide phases containing less oxygen than $\mathrm{Ta}_{2} \mathrm{O}_{5}$ have been reported to exist, the present study has shown only the two allotropic forms of $\mathrm{Ta}_{2} \mathrm{O}_{5}$. The phase which forms a platelike precipitate was identified as the low-temperature allotropic modification. The hightemperature modification was observed in specimens supersaturated with oxygen at the $1800 \mathrm{C}$ homogenizing temperature. This oxide phase forms spherical particles within the grains of tantalum as well as in grain boundaries. It appears that this phase forms at temperatures above $1500 \mathrm{C}$ while the platelike low-temperature modification of $\mathrm{Ta}_{2} \mathrm{O}_{5}$ precipitates at temperatures below $1500 \mathrm{C}$. The low-temperature form is crystallographically oriented with respect to the matrix lattice while high-temperature $\mathrm{Ta}_{2} \mathrm{O}_{5}$ grows at specific sites.

The etching characteristics of the tantalum-nitrogen alloys are interesting in that after the lower temperature $(1000$ and $500 \mathrm{C})$ anneals, etch pits formed which indicate a subgrain structure. This subgrain structure is probably due to lattice strains which develop prior to precipitation. Although the solubility of nitrogen in tantalum at $1500 \mathrm{C}$ was as great as the oxygen solubility, nitrogen has significantly lower solubility than oxygen at 1000 and $500 \mathrm{C}$. In the case of the supersaturated nitrogen alloys, the matrix lattice is highly strained by the precipitate. This strain is probably due to the epitaxial growth of nitride on the tantalum matrix lattice. The pseudo cell of the nitride phase is approximately 2 per cent larger than that of tantalum. The present metallographic studies have not distinctly shown the initial nitride precipitate, but it is believed to form in subgrain boundaries.

The solid-solubility limits of the interstitials, carbon, nitrogen, and oxygen, in tantalum at 1500,1000 , and $500 \mathrm{C}$ are shown in Figure 16. The solubility of oxygen at $1800 \mathrm{C}$ is also indicated based upon the results of the present study. X-ray diffraction data for the initial precipitate phases were obtained and are given in Table 5 . 


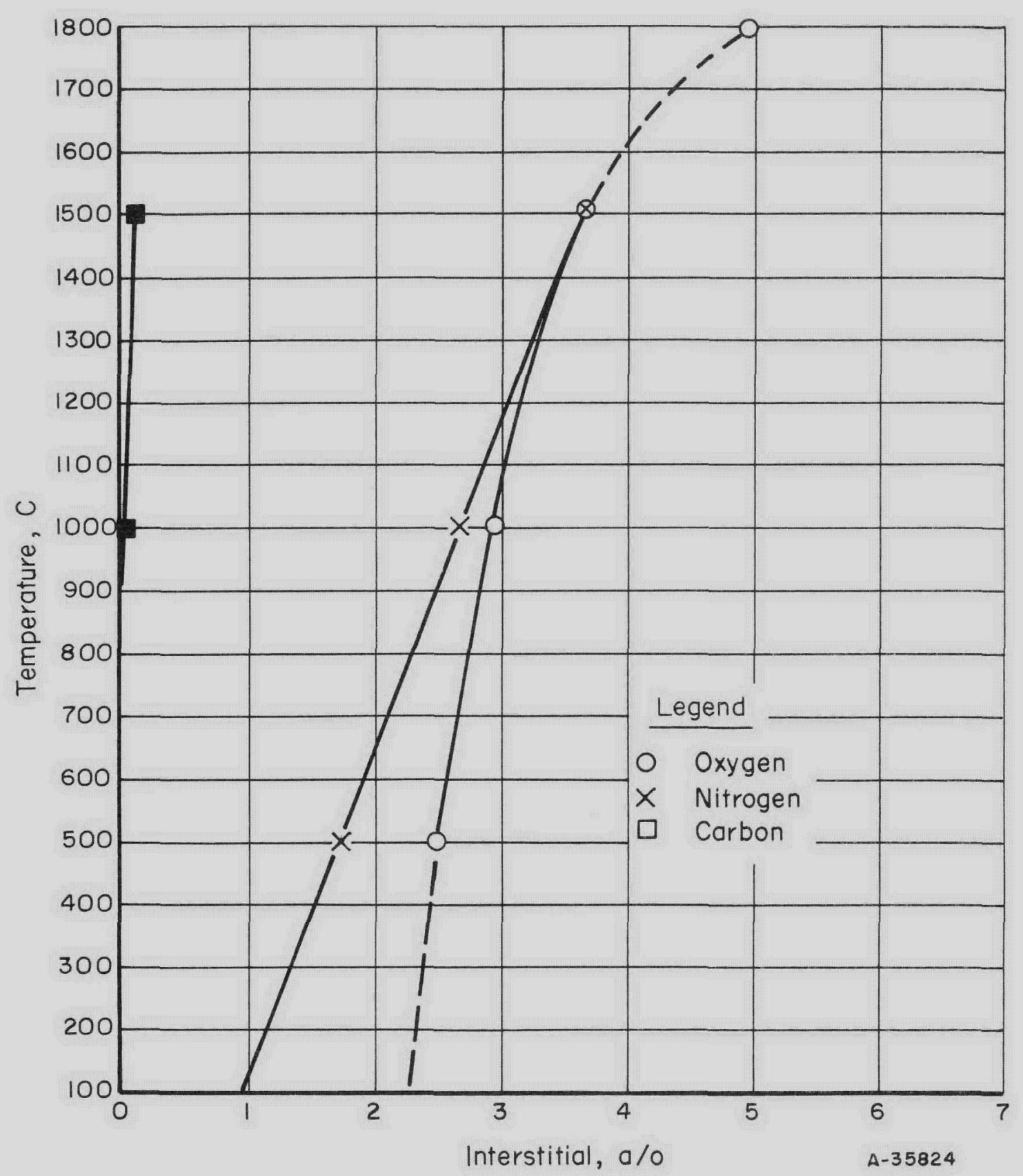

FIGURE 16. SOLID SOLUBILITY OF INTERSTITIALS IN TANTALUM BASED ON PRESENT X-RAY AND METALLOGRAPHIC STUDIES OF SPECIMENS QUENCHED FROM 1500, 1000, AND $500 \mathrm{C}$ 


\section{ACKNOWLEDGMENT}

The authors wish to express their appreciation to the following BMI staff members: D. Kohler for preparation of the alloys, M. W. Mallett and F. Huber for chemical assays, D. Kiefer for optical and electron metallography, and J. Lawton for obtaining the X-ray patterns. This work was conducted in assistance to Los Alamos Scientific Laboratory.

\section{REFERENCES}

(1) Gebhardt, E., and Seghezzi, H. D., "Investigations in the Tantalum-Oxygen System (1) Concerning the Mechanism of Oxygen Uptake at High Temperatures", Z. Metallk., 50, 248-257 (1959).

(2) Gebhardt, E. , and Preisedanz, H. , "Concerning the Solubility of Oxygen in Tantalum and the Related Property Changes", Z. Metallk., 46, 560-568 (1955).

(3) Gebhardt, E., Seghezzi, H. D., and Durrschnabel, W., "Studies on the TantalumNitrogen System", Z. Metallk., 49, 577-583 (1953).

(4) Schonberg, N., "An X-Ray Investigation of the Ta-O System", Acta Chem. Scand. , 8, 240-245 (1954).

(5) Lagergren, S., and Magneli, A., "On the Tantalum Oxygen System", Acta Chem. Scand. , 6 , 444 (1952).

(6) Schonberg, N., "An X-Ray Study of the Ta-N System", Acta Chem. Scand. , $\underline{8}$, 199-203 (1954).

(7) Ellinger, F. H., "The Tantalum-Carbon System", Trans. ASM, 31, 89 (1943).

(8) Lesser, R., and Braurer, G., "The Tantalum Carbon System", Z. Metallk., $\underline{49}$, 622-626 (1958).

DAV:OMS:CMS/mln 